
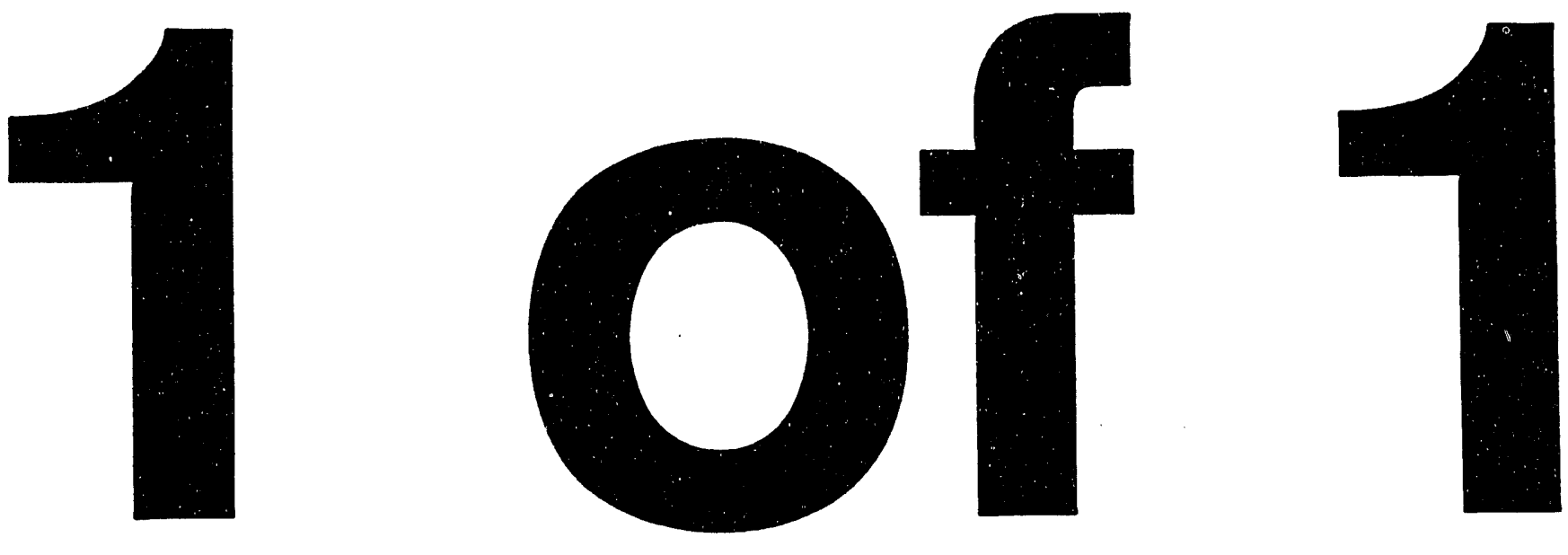


\section{RISK PERCEPTION on MANAGEMENT of NUCLEAR HIGH-LEVEL and TRANSURANIC WASTE STORAGE}
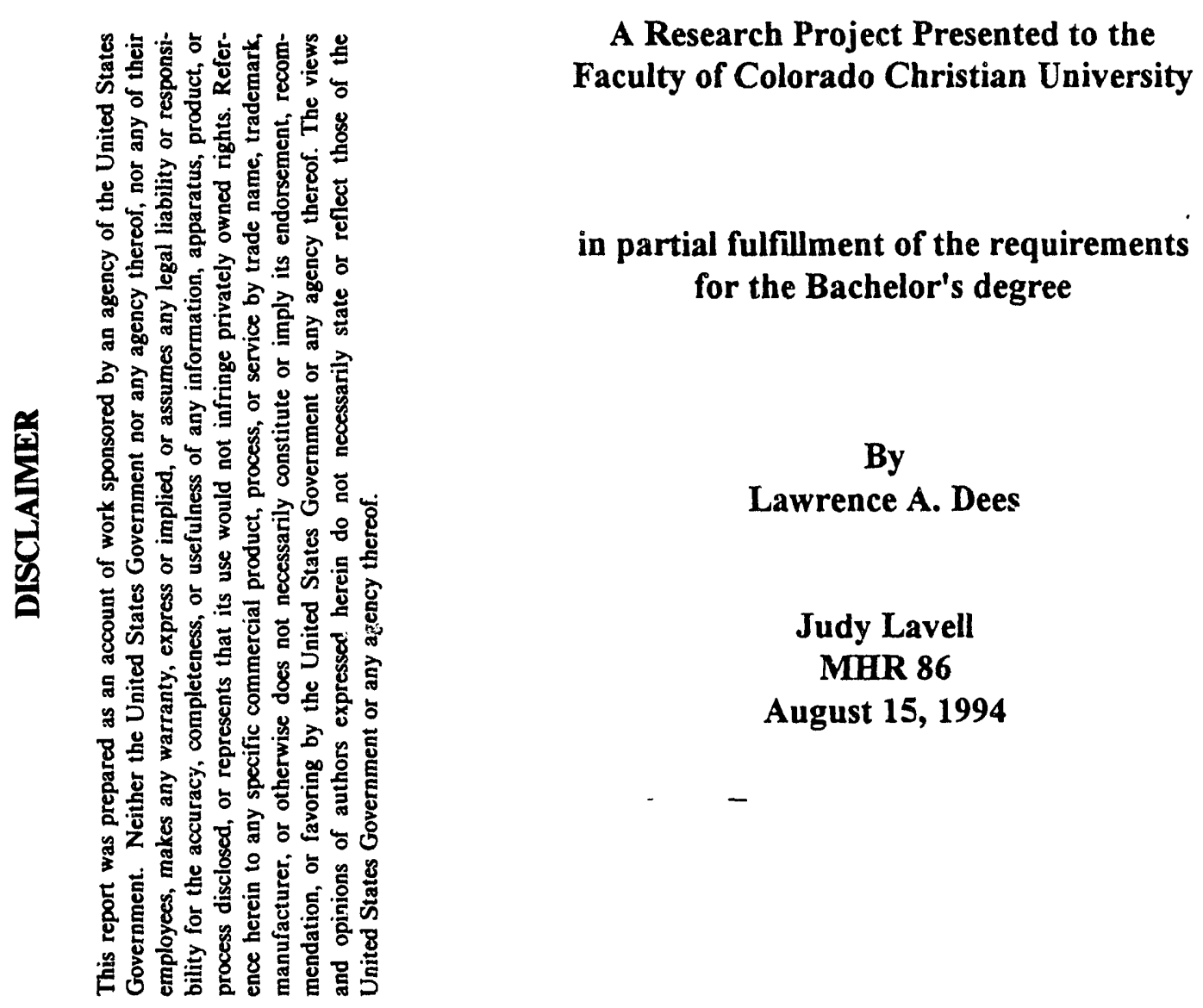


\section{CERTIFICATION PAGE}

This is to certify that the research prepared

By Lawrence A. Dees

Entitled Risk Perception on Management of Nuclear High-Level Waste and Transuranic

Waste Storage

Has been accepted by the Faculty of Colorado Christian University

Signed:

Project Professor

Date

Director Date

This Research Project is not to be regarded as confidential, and its use as a sample in future classes is not restricted. 


\begin{abstract}
The Department of Energy's program for disposing of nuclear High-Level Waste (HLW) and transuranic (TRU) waste has been impeded by overwhelming political opposition fueled by public perceptions of actual risk. Analysis of these perceptions shows them to be deeply rooted in images of fear and dread that have been present since the discovery of radioactivity. The development and use of nuclear weapons linked these images to reality and the mishandling of radioactive waste from the nations military weapons facilities has contributed toward creating a state of distrust that cannot be erased quickly or easily.
\end{abstract}

In addition, the analysis indicates that even the highly educated technical community is not well informed on the latest technology involved with nuclear $\mathrm{HLW}$ and TRU waste disposal. It is not surprising then, that the general public feels uncomfortable with DOE's management plans for with nuclear HLW and TRU waste disposal.

Postponing the permanent geologic repository and use of Monitored Retrievable Storage (MRS) would provide the time necessary for difficult social and political issues to be resolved. It would also allow time for the public to become better educated if DOE chooses to become pro-active. 


\section{TABLE OF CONTENTS}

\section{Title Page}

Certification Page............................................................................................................... i

Abstract .......................................................................................................................... ii

Table of Contents ............................................................................................................... iii

CHAPTER ONE - PROBLEM AREA _.............................................................. 1

Purpose of the Study ......................................................................................... 1

Problem Statement........................................................................................... 1

Hypotheses................................................................................................................... 2

Definition of Terms ............................................................................................ 3

Summary ...................................................................................................... 14

CHAPTER TWO -- PRECEDENCE IN RESEARCH.......................................... 15

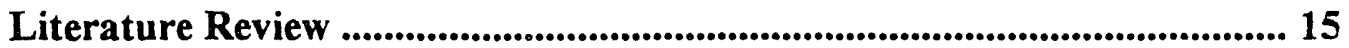

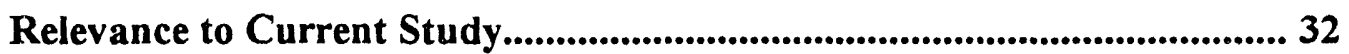

CHAPTER THREE -- RESEARCH DESIGN.......................................................... 38

Hypotheses.......................................................................................................... 38

General Methodology.......................................................................................... 38

Specific Procedures ............................................................................................... 39

Research Population/Sample ........................................................................... 40

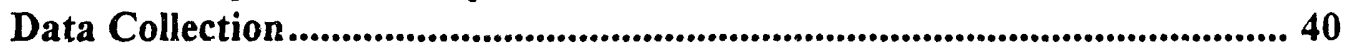

Treatment of Data ......................................................................................... 42

CHAPTER FOUR -- FINDINGS ................................................................. 44

Problem Statement....................................................................................................... 44

General Results ............................................................................................... 45

Hypotheses................................................................................................................ 47

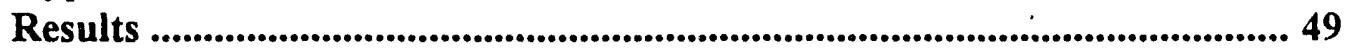

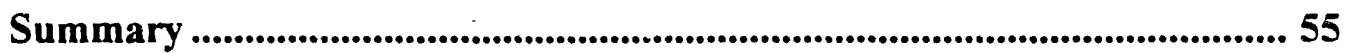

CHAPTER FIVE -- CONCLUSIONS.................................................................... 56

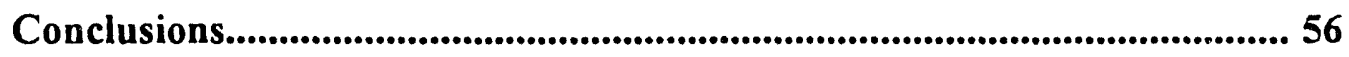

Conclusions Based on Findings .......................................................... 56

Alternative Explanations of Findings ................................................ 56

Limitations of the Study .......................................................................... 56

Implications.............................................................................................................. 57

Implications for Professional Practice or Decision Making............. 57

Implications for Future Research ........................................................ 60

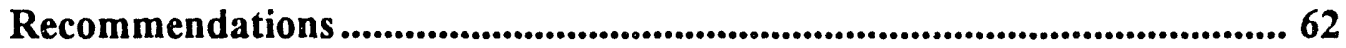

Recommendations for Policy Development..................................... 62

Recommendations for Professional Practice .................................... 66

REFERENCES................................................................................................................. 68 

APPENDIX A - COVER LETTER.
APPENDIX B - QUESTIONNAIRE
APPENDIX C - LEARNING OUTCOMES AT CCU
Concrete Experiences...................................................................................... 79

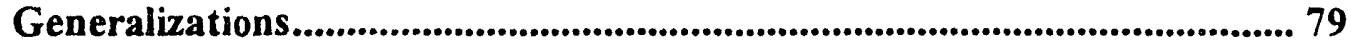

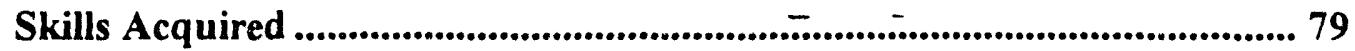
Personal Reflections ..................................................................................... 80 


\section{CHAPTER ONE -- PROBLEM AREA}

\section{Purpose Of Study}

The purpose of this project is to study the public and technical communities' perception on the risk involved with temporary, Monitored Retrievable Storage (MRS), and permanent nuclear waste storage repository. It is believed that the public and technical communities see the nuclear HLW and TRU problem from two entirely different perspectives. This study is an effort to provide quantitative research data to support the hypotheses that follow.

\section{Problem Statement}

The problem being studied for this project is the public and technical communities' perception on risk of nuclear HLW and TRU waste storage. Nuclear HLW and TRU waste are primarily generated 5om commercial power reactors and weapons facilities. Because of poor risk management by the U.S. Department of Energy (DOE) and Nuclear Regulatory Commission (NRC), the public feels like victims rather than beneficiaries of the technology created by the science and engineering community.

The scope of the project will involve the following issues. If the technical community handles nuclear HLW and TRU waste in a safe manner, then the local residents, as well as the ones in the next state, will feel comfortable with the long term storage in their back yard. This brings up a second issue. The longer we wait while deciding on a permanent repository for nuclear HLW and TRU waste, the higher the risk of an accident during temporary storage. This increases the risk of an accident while exposing a larger area of the country to that possibility. The third is the belief that the 
government will not be able to manage nuclear HLW and TRU waste any better than it has the rest of the nuclear industry.

While finding a permanent repository site for nuclear waste is one of the most urgent energy problems at the national and world levels, finding a site has dragged on for decades without a successful resolution. With present technology the problem appears to be as much political as technical. From past studies it is obvious that the public does not like nuclear waste. Another problem that effects public perceptions of risk is the record of federal mismanagement of radioactive wastes at the nation's military weapons facilities. According to the National Academy of Sciences (1989), leakage from these facilities has caused widespread environmental contamination, the cleanup of which is projected to cost more than $\$ 150$ billion over the next 30 years. Moreover, the recent revelation that the Hanford Weapons Plant, located near Richland, Washington, released unprecedented amounts of radiation in the 1940s and 1950s will certainly compound the negative imagery associated with the nuclear waste repository and further undermine public trust in government management of nuclear waste disposal.

\section{Hypotheses}

H1: The better our technical community takes care of nuclear HLW and TRU waste, the more comfortable the residents feel.

H2: The longer we wait to decide on a permanent repository for nuclear HLW and TRU, the higher the risk of an accident during temporary storage at the present facilities.

H3: With the track record of government in the nuclear field, the public no longer trusts their nuclear $\mathrm{HLW}^{\prime}$ and TRU waste management plans. 


\section{Definition Of Terms}

$A L A R A$ is the attempt to keep exposure to hazardous material As Low As Reasonably Achievable.

Alpha radiation is one of the three principle radiation's emitted by radioactive substances. The radiaiion's are made up of electrically-charged particles that consist of two neutrons and two nre tons. Their electrical charge is positive. Though alpha particles cannot penetrate clothing, they are extremely damaging when taken internally.

Aquifer is a subsurface formation or geologic unit containing sufficient saturated permeable material to yield significant quantities of water.

Atom is the basic building block of all matter. It is the smallest part of an element, and has all the chemical properties of that element. It consists of protons and neutrons in the nucleus, plus electrons.

Atomic half-life is the length of time it takes half of the atoms in a radioactive substance to decay.

Background radiation is radiation from natural radioactive materials always present in the environment. Included is radiation's from cosmic rays or the sun, the naturally radioactive elements of the earth, the atmosphere, building materials, and the bodies of humans and animals. 
Beta radiation is one of three principle radiation's emitted by radioactive substances. They are composed of electrically-charged particles. Their charge is negative. The particles have a mass and charge equal to that of electrons. They have little ability to penetrate other materials and move with high velocities up to 180,000 miles per hour. Beta particles cannot penetrate heavy metal, but can cause skin cancer, and are harmful when taken internally.

Borosilicate glass consists mostly of sand and borax, used to solidify liquid high-level radioactive waste.

Canister is a container in which high-level wastes are placed for permanent burial.

Cask is container in which high-level wastes are transported for burial.

Chain reaction is a self-sustaining reaction occurring in nuclear fission when the number of neutrons released equals or exceeds the number of neutrons absorbed plus the neutrons that escape from the reactor.

Commercial waste is the radioactive waste generated in the production of nuclear energy for commercial purposes. Commercial production can produce both high and low-level wastes.

Curie $(\mathrm{Ci})$ is a measure of the rate at which radioactivity decays. The quantity of any radioactive atom of a specific nuclear constitution in which the number of disintegration's per second is 37 billion, approximately that occurring in one gram of radium.

Decay heat is the heat produced by the decay of radioactive particles. 
Decommissioning is the process of removing a facility or area from operation and decontaminating and/or disposing of it or placing it in a condition of standby with appropriate controls and safeguards.

Defense waste is radioactive waste generated in the production of nuclear energy for defense purposes. The wastes are generated in a variety of activities, including weapons research and development, the reprocessing of spent fuels, the operation of reactors on nuclear-powered s'ips and submarines, and the decommissioning of those vessels. The wastes are known as government wastes.

Electrons are electrically-charged particles which revolve around the atomic nucleus. The electrical charge is negative. It is the lightest known particle that possesses an electrical charge.

Emitter is an element that emits charged particles or gamma rays from the nucleus of an atom.

Erg is a unit of energy.

Fission is the process of generating a nuclear reaction by splitting or breaking open atoms of heavy weight into two roughly equal parts, accompanied by the release of a relatively large amount of energy and frequently one or more neutrons.

Fission product is the general term used for over 200 different nuclides of over 35 different elements produced as a result of nuclear fission. Most fission products are radioactive. 
Fuel assemblies A bundle of fuel rods and their related hardware which have been arranged for efficient operation of a nuclear reactor.

Fuel rods are the stainless steel or zirconium tubes into which uranium pellets are placed for insertion into a nuclear reactor.

Fusion is the process of generating a nuclear reaction by joining the nuclei of certain atoms rather than splitting them as is done in the fission process.

Gamma radiation is one of the three principle radiation's emitted by radioactive substances. It is high-energy, short-wavelength electromagnetic radiation emitted by a nucleus. Gamma radiation usually accompanies alpha and beta emissions.

Half-life is the time in which half the atoms of a given quantity of a particular radioactive substance disintegrate to another form.

High-Level waste $(H L W)$ is defined by a DOE order as "the highly radioactive waste material that results from the reprocessing of spent nuclear fuel, including liquid waste produced directly in reprocessing and any solid waste derived from the liquid, that contains a combination of transuranic waste and fission products in concentrations requiring permanent isolation." SOURCE: DOE Order 5820.2A

High-Level Waste (HLW) is defined by the NRC as: 1) irradiated reactor fuel; 2) liquid wastes resulting from the operation of the first cycle solvent extraction system, or equivalent, and the concentrated wastes from subsequent extraction cycles, or equivalent, in a facility for reprocessing irradiated reactor fuel; and 3) solids.

SOURCE: 10 CFR Part 60 
High-Level Waste (HLW) defined by the NWPA: 1) the highly radioactive material resulting from the reprocessing of spent nuclear fuel, including liquid waste produced directly in reprocessing, and any solid material derived from such liquid waste that contains fission products in sufficient concentrations; and 2) other highly radioactive material that the NRC, consistent with existing law, determines that by rule requires permanent isolation. SOURCE: Public Law 97-425

In situ vitrification (ISV) is a technology for immobilizing buried waste or contaminated soil. A high current flowing through giant electrodes, in or near the media to be vitrified, melts the material, which then hardens into a glasslike solid.

Incinerator is a device used to burn toxic and radioactive trash. Radioactive byproducts of the combustion process are collected as radioactive ash or released as gases into the environment.

Ionizing radiation is radiation capable of displacing electrons from atoms. The process produces electrically charged atoms such as X-rays, alpha, beta, and gamma rays.

Irradiation is radiation used in medicine to treat diseased tissue by exposure to X-rays, ultraviolet rays, radium, or some form of radiant energy.

Isotope is one or two or more forms of an element that differ in atomic weight. Nuclides have the same atomic number and the same number of protons, but a different number of neutrons in the nucleus. 
Long-lived nuclides are radioactive isotopes with half-lives greater than about thirty years. Most long-lived nuclides of interest to waste management have half-lives longer than thousands of years.

Low-level waste is waste containing types and concentrations of radioactivity such that minimum shielding is required.

Mass number is the number of neutrons and protons in an atom. The mass number of uranium-238, for example, is 238 , consisting of 146 neutrons and 92 protons.

Maximum permissible concentration (MPC) is the amount of radioactive material in air, water, or food that would result in a dose of 500 millirems per year to the whole body, or 1,500 millirems per year to a specific organ, as given in Section II, Table B, of the Nuclear Regulatory Commission regulations, 10 CFR Part 20.

Millirem is one-thousandth of a rem. See Rem.

Monitored retrievable storage (MRS) will provide temporary, above-ground storage for spent fuel shipped from commercial nuclear reactors that generate electricity. When the geologic repository begins operating, spent fuel will be shipped from the $M R S$ facility to the repository for permanent disposal. Technically suitable sites for the $M R S$ facility can be found throughout the United Stated.

Neutron is an uncharged subatomic particle found in the nucleus of every atom heavier than hydrogen. They have approximately the same mass as a proton. Low energy neutrons can induce fission in fissionable materials. Neutrons sustain the fission chain reaction in nuclear reactors. 
Noble gases are gases such as helium, neon, and argon that are inert chemically.

Nucleus is the case of an atom. The nucleus made up of protons and neutrons.

Nuclide is a type of atom characterized by the makeup of its nucleus -- namely, by the number of protons and neutrons and the energy content in the nucleus.

NWTRB is the Nuclear Waste Technical Review Board

Plutonium is a radioactive element with an atomic number of 94 , produced during the fission process. In its separated form, it can be made into either nuclear fuel or a nuclear explosive.

Primordial radionuclide is a radionuclide that has existed from the time of the origin of the earth. Its half-life extends into billions of years.

Proton is an electrically charged particle in the nucleus of an atom. Their electrical charge is positive.

Public and technical communities for this paper will be defined as follows:

These parties include the public and its elected representatives; affected states, units of local government, and Indian Tribes; the electric utilities, their ratepayers, and the ratesetting bodies; Federal agencies; and the scientific community.

PUREX is the acronym for Plutonium and URanium EXtraction, a series of chemical processes for extracting, separating, purifying, and concentrating plutonium, uranium, and 
neptunium from irradiated fuel. It uses nitric acid and tributyl-n-phosphate in a kerosene solvent.

Radiation absorbed dose (RAD) A rad of radiation exposure is equal to 100 ergs of radiation energy deposited in one gram of matter,

Radiation is the process of emitting radiant energy in the form of waves or particles.

Radionuclides are nuclides that are radioactive.

Radioactive decay is the property of undergoing spontaneous nuclear transformation in which nuclear particles or electromagnetic energy is emitted.

Radioactivity is the spontaneous emission of alpha or beta and sometimes gamma radiation from the nucleus of an atom.

Radiolytic relates to the chemical decomposition by the action of radiation.

Reactor is a device in which atoms are fissioned. Also known in the past as atomic furnace.

Reactor core is the heart of the nuclear reactor, the area in which fissioning takes place.

REDOX is an older chemical process, now replaced with the PUREX process, to extract, separate, purify, and concentrate plutonium, uranium, and neptunium. 
Repository is an installation for the permanent storage of high-level and/or low-level nuclear wastes. It is usually an underground facility. It can also be called a depository.

Reprocessing is the process of chemically removing uranium and plutonium from nuclear fuel rods so that the two elements can be reused.

Resuspension is when radioactive particles have been spread on the ground and then once again suspended in the air as a result of wind, plowing, etc.

Roentgen equivalent man (rem) is the dosage of any ionizing radiation that will produce a biological effect approximately equal to that produced by one roentgen of X-ray or gamma radiation. The rem is defined as a dose of a particular type of radiation required to produce the same biological effect as one roentgen of gamma radiation.

Roentgen $(R)$ is a measure of the ability of gamma or X-rays to produce ionization in the air. One roentgen corresponds to the absorption of about 86 ergs of energy from X-ray or gamma-ray radiation per gram of air. The corresponding absorption of energy in the tissue may be from one-half to two times as great.

Saltcrete is a mixture of concrete and radioactive waste residue from the vitrification process.

Shielding is material that has been successfully used as a shield for human beings and the environment from radiation. The materials best used for the shielding of nuclear HLWs are lead, concrete, steel, and water. 
Short-lived nuclides are radioactive isotopes with half-lives not greater than thirty years, such as cesium 137 and strontium 90.

Somatic cells are any cells of an organism that become differentiated into the tissue of the body.

Special nuclear material (SNM) is plutonium, uranium-233, highly-enriched uranium, uranium 235, and any other materials that the Nuclear Regulatory Commission determines to be SNN.'s.

Spent (Nuclear) Fuel is fuel that has been withdrawn from a nuclear reactor following irradiation, but that has not been reprocessed to remove its constituent elements.

Supercompactor is a hydraulic press generating 1500 to 2200 tons of force; used to greatly reduce the volume of compactible radioactive waste.

Supercritical is when there is a sufficient mass of fissionable plutonium or uranium so that a self-supporting and multiplying chain reaction occurs.

Transuranium (Transuranic) Radionuclide (TKL') is any radionuclide having an atomic number greater than 92. TRU is further defined as: without regard to source or form, waste contaminated with alpha-emitting transuranium radionuclides with half-lives of more than twenty years and concentrations higher than 100 nanocuries per gram.

Trinotrotuluene (TNT) is a type of high explosive. 
Tritium is a radioactive isotope of hydrogen with a nucleus of two neutrons and one proton. A beta emitter with a half-life of twelve years.

Uranium is a slightly radioactive element employed in the production of nuclear energy. Its atomic number is 92 and atomic weight is about 238 . The two principles naturally occurring isotopes are uranium 235 (fissionable) and uranium 238.

Waste Isolation Pilot Plant (WIPP) Is underground repository for transuranic waste and experimental borosilicate glass high-level waste logs being constructed in New Mexico. Recent leakage problems have put large-scale disposal plans on hold.

Whole-body dose is a radiation dose to the whole body. 


\section{Summary}

The purpose of this project is to study the public and technical communities' perception of the risk involved with temporary, MRS, and permanent nuclear HLW and TRU waste storage repositories. The development of the waste management system for nuclear HLW and TRU waste storage, transportation, and disposal is a complex undertaking that poses the unprecedented technical challenge of demonstrating the expected performance of a repository for thousands of years into the future.

The program is made more complex by the involvement of a wide variety of affected and interested parties with disparate views and goals. These parties include the public and its elected representatives; affected states, units of local government, and Indian Tribes; the electric utilities, their ratepayers, and the rate-setting bodies; Federal agencies; and the scientific community participating as represented in the program. Ensuring that these parties are fully informed and enabled to exercise their roles will be a continuing challenge for the DOE and NRC. 


\section{CHAPTER 'TWO - PRECFDENCE IN RESEARCH}

\section{Literature Review}

It is projected that by the year 2000 , the United States alone will have a projected 40,000 metric tons of spent nuclear fuel stored at some seventy sites awaiting disposal (Stovic, Flynn, \& Layman, 1991). By 2035, after all the existing nuclear plants have completed forty years of operation, there will be approximately 85,000 metric tons (3rd Report to Congress). The DOE has been under intense pressure from Congress and the nuclear commercial industry to dispose of this accumulating volume of HLW and TRU waste since the passage of the Nuclear Waste Policy Act (NWPA) in 1982 and its amendment in 1987, by which Yucca Mountain located in Nevada, was selected as the only candidate for the nation's first nuclear waste repository. The lack of a suitable solution to the waste problem is widely viewed as an obstacle to further development of nuclear power and a threat to the continued operation of existing reactors, besides being a safety hazard in its own right.

Yet, at this time the DOE program has nearly been brought to a halt by overwhelming political opposition, fueled by perceptions that the risks are immense (Stovic, Flynn, \& Layman, 1991). These perceptions stand in stark contrast to the prevailing view of the technical community which argues that nuclear waste can be disposed of safely, in deep underground isolation. Officials from DOE, the commercial nuclear industry, and their technical experts are profoundly puzzled, frustrated, and disturbed by public and political opposition that many of them consider to be based on

irrationality and ignorance. Lewis (1990, chap. 9, pp. 245-246), for example, argued that the risk from a properly constructed repository, "...is as negligible as it is possible to 
imagine... It is embarrassingly easy to solve the technical problems, yet impossible to solve the political problems... High-level nuclear waste disposal is a non-risk."

The public complains about the nuclear community, but seems to forget that we are surrounded by radiation in our daily lives. We live safely with radiation every day. It comes from the food we eat, the water we drink, from the earth and from the sun. In fact, radiation in some form or another has been on the planet longer than man.

More than three-fourths of the radiation we receive comes from natural sources like the sunlight, soil, and certain types of rocks. This is called background radiation.

Medical procedures like x-rays and common household items like color televisions and smoke detectors are all sources of what is called man-made radiation, which accounts for the remaining one-fourth of 'sur radiation exposure. There is no difference between natural radiation and man-made radiation. Last year approximately 10 million nuclear medical procedures were performed in the United States. Diagnostic x-rays and/or radiation therapy helped millions of people get well.

The study of radiation begins with the atom. Atoms are the building blocks of the universe. Natural forces hold them together, and they make our world look the way it does. Tremendous amounts of energy are stored in the centers -- called the nuclei -- of atoms. When atoms are split, two things are produced: one is heat, the other is radiation. Radiation is measured in units called millirems. A millirem measures the effect of radiation on our bodies just as degrees measure temperature and pounds measure weight.

An average American's exposure to radiation is about 360 millirems per year. About 300 millirems of that 360 come from natural sources of radiation; 60 millirems 
Figure 1-1 -- Schematic of High-Level Waste Generation, Treatment, and Disposal

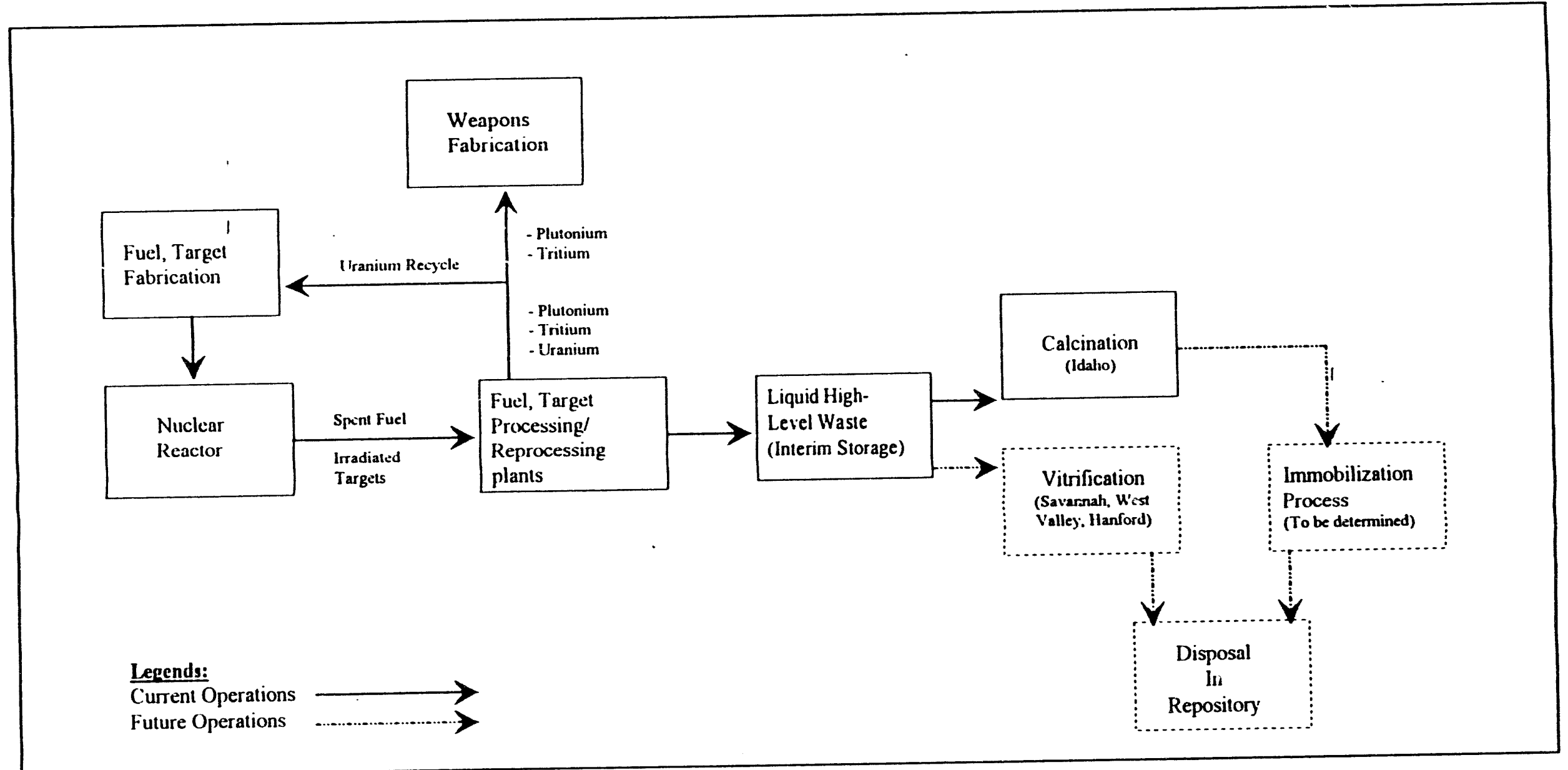


come from man-made sources, primarily medical procedures; and less than one millirem cones from the use of nuclear fuel.

Location also plays a part in how much radiation a person receives. A person living in Egypt receives 300 to 400 millirems per year. A person living in Brazil receives 500 millirems per year. A person living in certain parts of India receives 1,300 millirems per year, more than three and one-half times as much as a person living in the U.S. receives.

Standards for protection of the public from the effects of radiation have been in existence for mcre than forty years. Maximum exposure for the general public from the operation of a nuclear facility licensed by the NRC, including a MRS facility, a Federal central storage facility for spent nuclear fuel, is 25 millirems per year. This limit is in accord with exposure standards set by the U.S. National Council on Radiation Protection, and Measurement, the International Commission on Radiation Protection, and the International Atomic Energy Agency. Exposures far below this limit will be realized by employing conservative design features and adhering too strict written and approved operating procedures for all fuel handling operations. Moreover, a management philosophy will be applied to facility operations to ensure that actual doses to the public will not exceed the allowable limit, but are also as low as reasorably achievable (ALARA).

Actual exposure for any individual is expected to be far below the limit, even if that individual was standing at the MRS site boundary 24 hours a day for 365 days a year. A realistic estimate for exposure for an individual living nearest to the MRS facility is expected to be on the order of one or so millirems. This is the same amount of exposure that the average individual in the United States gets in one day due to natural background radiation. Compare this to the additional 5 millirems one would get from a one week ski 
vacation in Denver, including the flight. The maximum exposure for a worker in a licensed nuclear facility is 5,000 millirems per year. The purpose of these, and the following comparisons, is not to trivialize the subject of radiation exposure, but simply to place such exposures into perspective.

- A person living directly outside a nuclear power facility would add approximately 1 millirem per year.

- A person working in a nuclear power plant would add 300 or more millirems per year.

- From cosmic rays alone, a person living in Washington DC, a city with a low elevation would receive approximately 26 millirems per year. A person living in Denver, Colorado, a city with a high elevation, would receive approximately 50 millirems a year.

- A person flying in an airplane across the country would add about 5 millirems per flight because of the increased elevation during the trip. Airline pilots and flight attendants are exposed to higher levels of radiation routinely due to their occupation.

- A person receiving a full set of dental $x$-rays would add about 40 millirems per year.

- A person working in a store on a street that a truck transporting nuclear waste passes by every week would add about one-half a millirem per year.

- A person stuck in traffic for an hour next to truck carrying nuclear waste would add less than 10 millirems.

- A person sitting on a park bench as a truck carrying nuclear waste passes by would add less than one-tenth of a millirem.

In the United States, there are four classifications of radioactive wastes; low-level (LLW), high-level (HLW), transuranic (TRU), and tailings that are byproducts of uranium mining and milling. The two of most concern are HLW and TRU. 
The nuclear reactors operated by the Nation's electrical utilities currently generate about 2,000 metric tons of spent fuel per year. This is relatively small quantity. For example, chemically hazardous wastes regulated under the Resource Conservation and Recovery Act (RCRA) are produced at a rate of $150,000,000$ metric tons per year.

For more than forty years, scientists and government officials have studied techniques for the permanent disposal of nuclear waste. Options have included disposal under deep sea sediments, within polar ice sheets, and by rocketing into outer space.

According to Long-Lived Legacy (1991), the first high-level defense waste was created as a byproduct of the production of plutonium in a natural uranium-graphite reactor at Hanford, near Richland, Washington, and the subsequent remote "reprocessing" of irradiated uranium fuel elements to recover plutonium. The byproduct was a highly radioactive, acidic, aqueous solution containing a variety of fission products with a wide range of half-lives, as well as residual uranium and some residual radionuclides with larger atomic numbers than uranium - the transuranics (TRU). It was recognized that this liquid HLW required careful handling, as well as isolation from people and the environment for many years. HLW is generally distinguished from other radioactive waste types by its intense radioactivity coupled with the longevity of its hazard. Huge underground, singleshell carbon steel tanks, eventually 149 in number, were built to store neutralized liquid HLW at Hanford. An early practice of discharging some of the liquid from HLW tanks into "cribs" and then into the soil was subsequently discontinued. When some tanks began to leak, new tanks of double-shell design were added.

Today, most liquid HLW has been neutralized, forming mixtures of liquid, sludge, and salt cake, and is currently stored on-site in steel tanks. Some of these steel tanks have leaked and represent a potential threat to groundwater. Storage of waste after 
neutralization of acidic HLW in less expensive carbon steel tanks, rather than stainless steel tanks requires complicated waste handling and treatment. There is also concern about the possibility of fire or explosion in the waste tanks, accompanied by the release of radioactivity.

It has been only fifty years since elements heavier than uranium -- hence, TRU -were created. These elements are not thought to occur in nature and were first produced in nuclear reactors as part of the World War II effort by the United States to develop the atomic bomb. An isotope of one of these elements, plutonium ${ }^{239}$, has physical and nuclear properties that make it a desirable material for atomic weapons -- only a few kilograms or tens of kilograms are required. Plutonium was the explosive material in the bomb dropped on Nagasaki. It is found in the "triggers" of tens of thousands of modern thermonuclear weapons in the arsenals of the United Stated and the Soviet Union. Whereas in the early 1940s, scientists working on the wartime Manhattan Project struggled to produce microgram quantities of plutonium ${ }^{239}$, tons of it exist today!

Threats to human health from plutonium and other transuranics do not arise solely from the possibility of their use in a thermonuclear conflict. Most transuranic radionuclides decay by emitting helium nuclei -- that is, alpha particles, a heavily ionizing form of matter. These alpha particles make plutonium toxic to humans in very small quantities when inhaled or ingested. Furthermore, some transuranic radionuclides are very long-lived and tend to persist rather than decay rapidly to other nuclides. A principle concern is plutonium ${ }^{239}$, which has a half-life of 24,000 years; this means that half of the plutonium ${ }^{239}$ in existence in 1994 will still exist in the year $26,390$.

Plutonium ${ }^{239}$ is produced via capture of neutrons by uranium ${ }^{238}$ in nuclear reactors. This process goes on continually in commercial nuclear power reactors, as it did in the 
Hanford reactors for weapons production purposes during and after World War II. In the U.S. commercial sector, almost all of the plutonium is contained within the solid structure of the spent fuel elements removed from the reactors. However, in the defense sector, plutonium is spread more widely in the environment because fuel elements and targets have been reprocessed, by using aqueous and organic liquids, to unlock and separate the plutonium for recovery and incorporation into weapons. Reprocessing has resulted in contamination by plutonium of soil and sediments in the vicinity of certain sites in the Nuclear Weapons Complex. In addition, contamination of workers and workplaces from various plutonium handling and machining operations is a constant concern. One example of this is the report from DOE in 1990 that enough plutonium had accumulated in the Heating, Ventilating, and Air Conditioning (HVAC) ducts at the DOE Rocky Flats Plant, near Denver, Colorado, to fuel several nuclear weapons.

TRU waste arises in the U.S. defense program primarily as a consequence of reprocessing plutonium-bearing fuel and irradiated targets, and from operations required to prepare the recovered plutonium for weapons use. TRU waste includes TRU metal scraps as well as glassware, process equipment, soil, laboratory waste, ion-exchange resins, clothing, High Efficiency Particulate Air (HEPA) filters, glove boxes, and paper products contaminated with TRU materials.

Until 1970, TRU waste was iandled in a manner similar to low-level waste (LLW): it was dumped into trenches or pits as seen in Figure 2-1 and covered over or buried; such waste is referred to as buried TRU waste. Pre-1970 practices have resulted in great uncertainty in the estimates and location of buried TRU waste and TRUcontaminated soil. Subsequently, in accordance with a 1970 Atomic Energy Commission (AEC) decision, TRU waste was stored, usually in metal drums, (reference Figure 2-2) in a manner to permit easy recovery and treatment, because of the growing realization that 


\section{Most buried TRU waste was dumped randomly.}

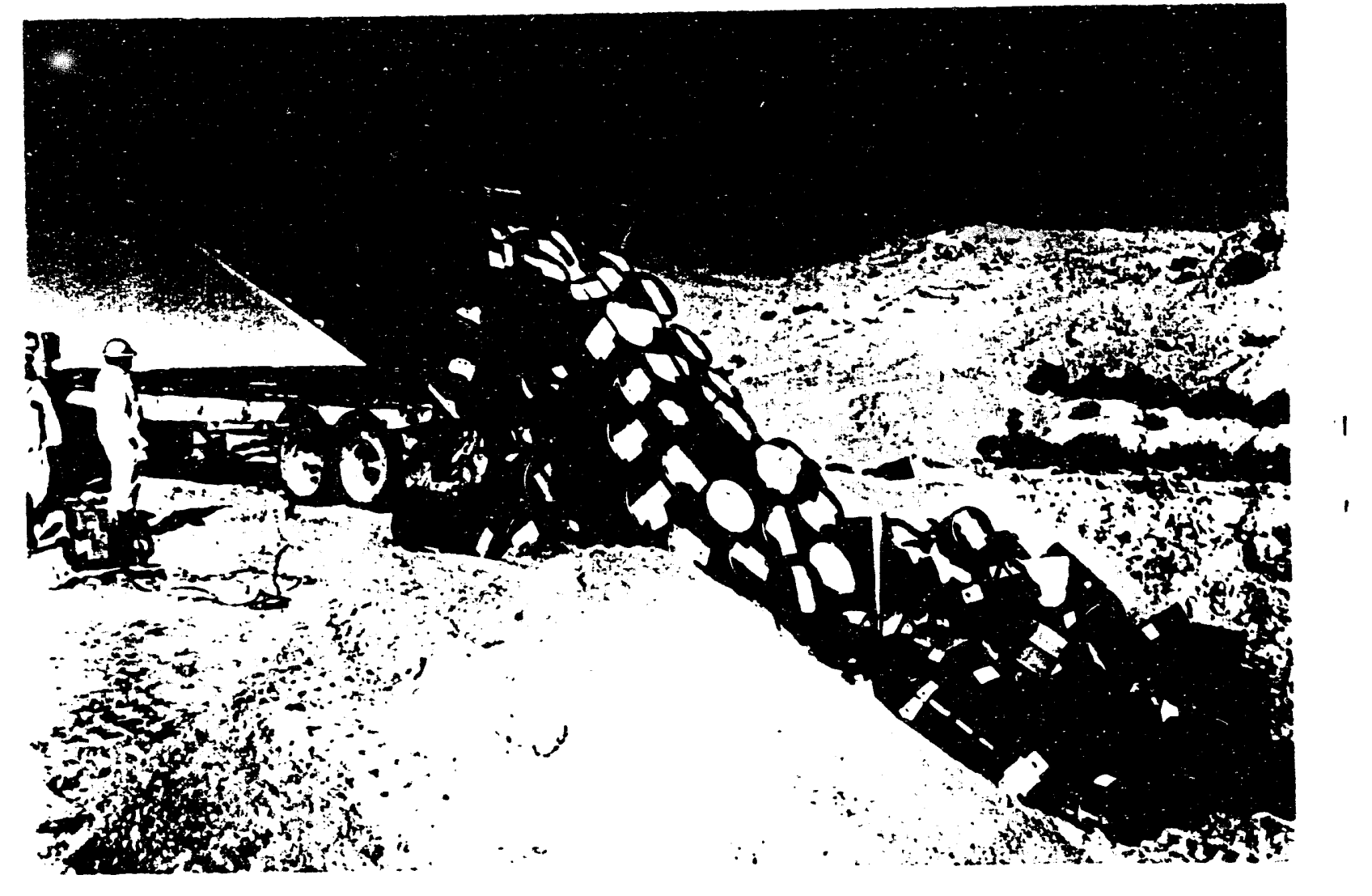




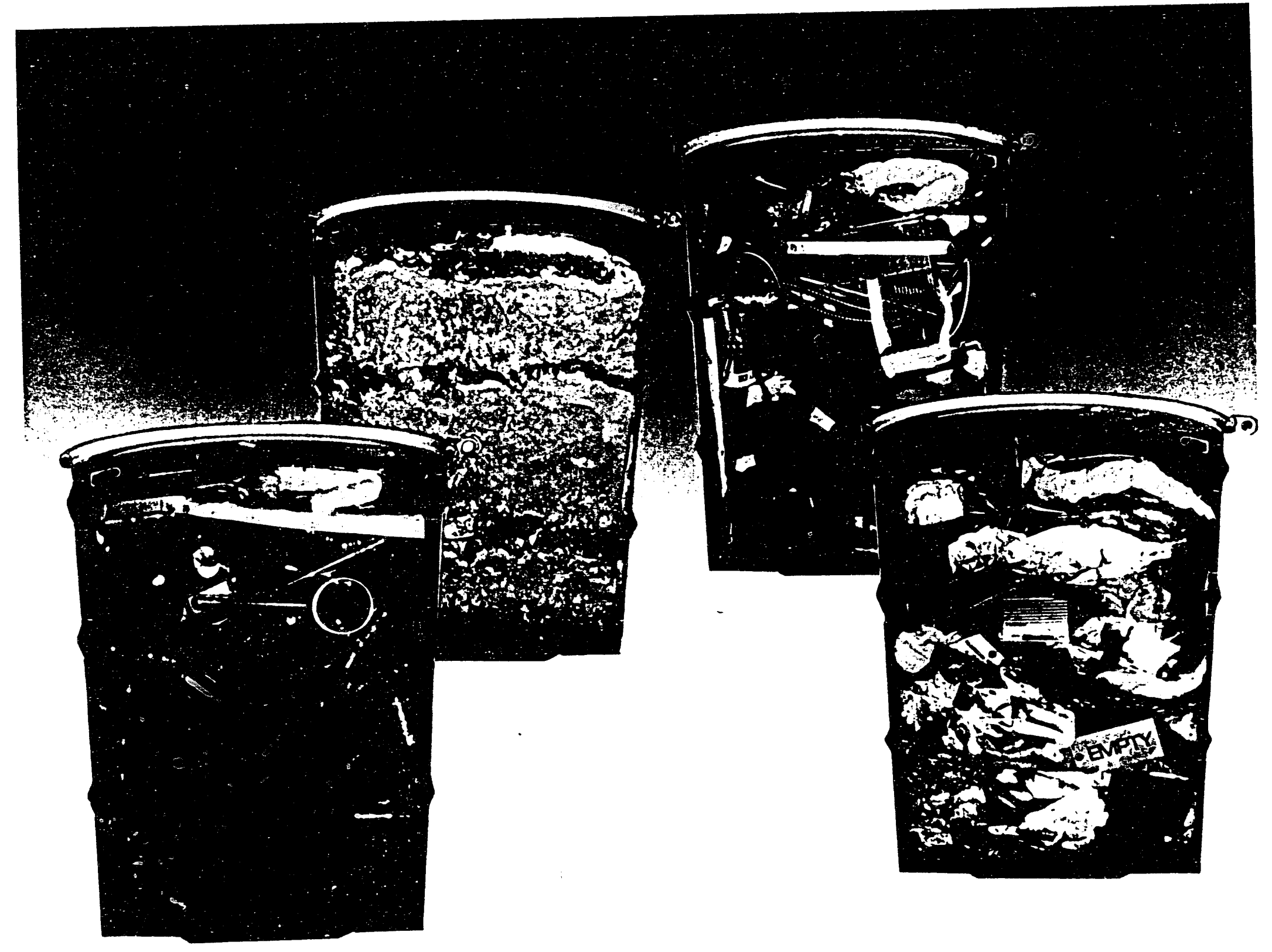


long-lived radionuclides such as plutonium ${ }^{239}$ require more careful handling, storage, and long-term disposal than previously recognized; such waste is referred to as retrievably stored TRU waste. In general, the DOE views retrievably stored and yet-to-be-generated waste as a waste management problem, whereas buried waste is an environmental restoration problem; The two may require different technological, evaluative, and administrative approaches. Since the mid-1970s, plans for long-term disposal of TRU waste have centered upon the availability of a deep geologic repository, paralleling earlier thinking about disposal of HLW.

DOE's policy is that retrievably stored and yet-to-be-generated TRU waste will be disposed of in a geologic repository. The Waste Isolation Pilot Plant (WIPP) near Carlsbad, New Mexico, was authorized by Congress in 1980 to serve as a research facility for disposal of such TRU waste in bedded salt. Upon completion of the test phase, WIPP might then serve as the first deep geologic repository for defense TRU waste. WIPP has now been built. To date, no waste packages have been placed in WIPP. A positive decision by Secretary of Energy James D. Watkins on DOE's readiness to proceed with the experimental stage was made in June 1990. The earliest date for disposal of TRU waste in the WIPP facility on a regular basis is 1995 . Other scenarios foresee WIPP opening much later.

WIPP is designed to bury plutonium-tainted waste from the U.S. defense industry 2,150 feet underground in ancient salt beds. The salt beds were chosen for a repository because salt will encase radioactive material. Over 70 to 100 years salt will move into mined areas and entomb the waste, separating the radioactivity from the environment. 


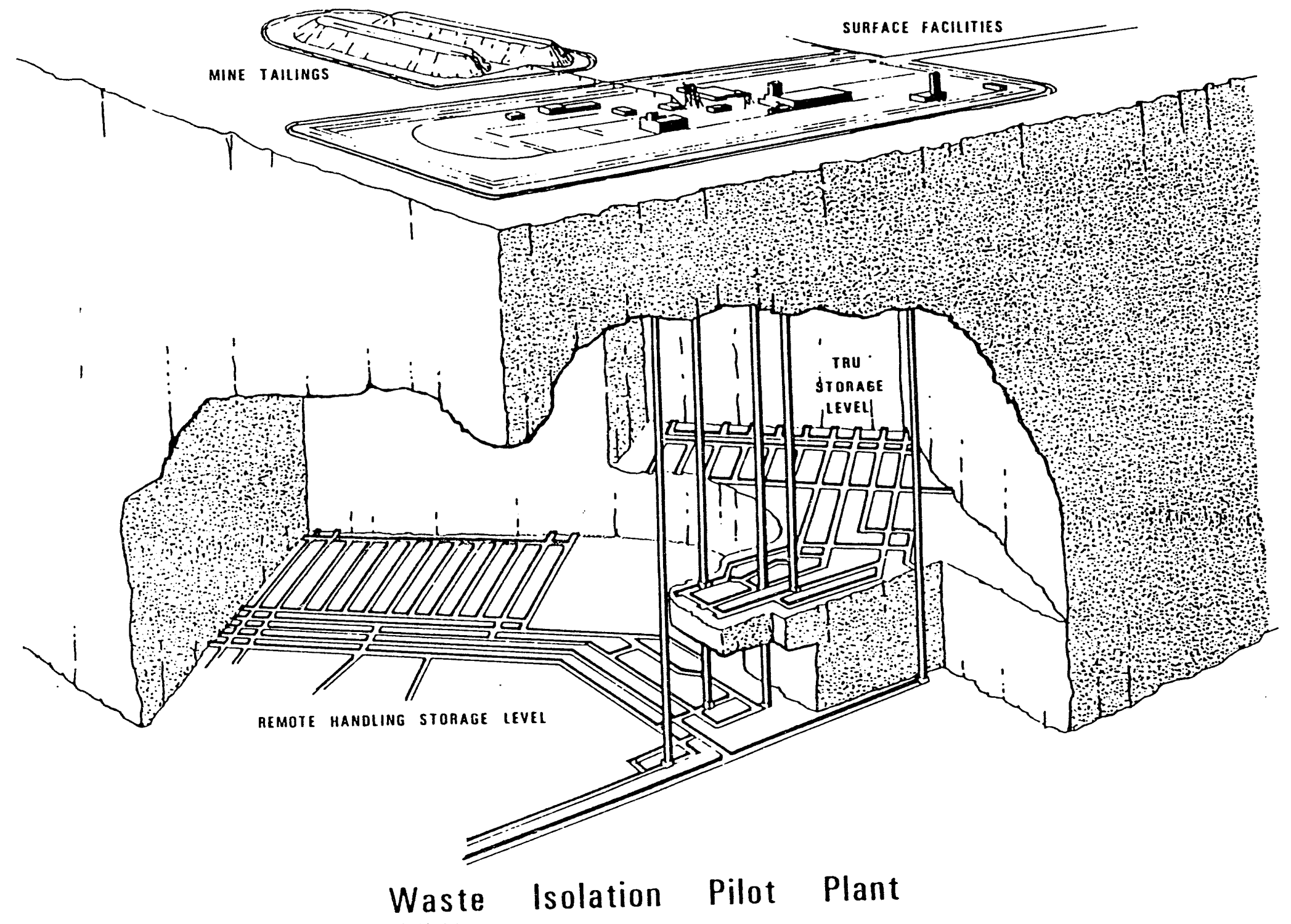

Fig. 1. Attist's Concept "l Wll'.

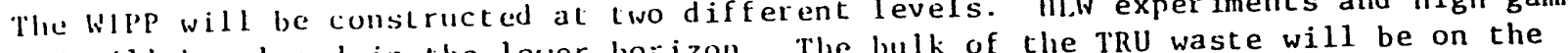
lRll will be placed in the lower hoizon. The bulk of the rex wasting rooms are filled. u 

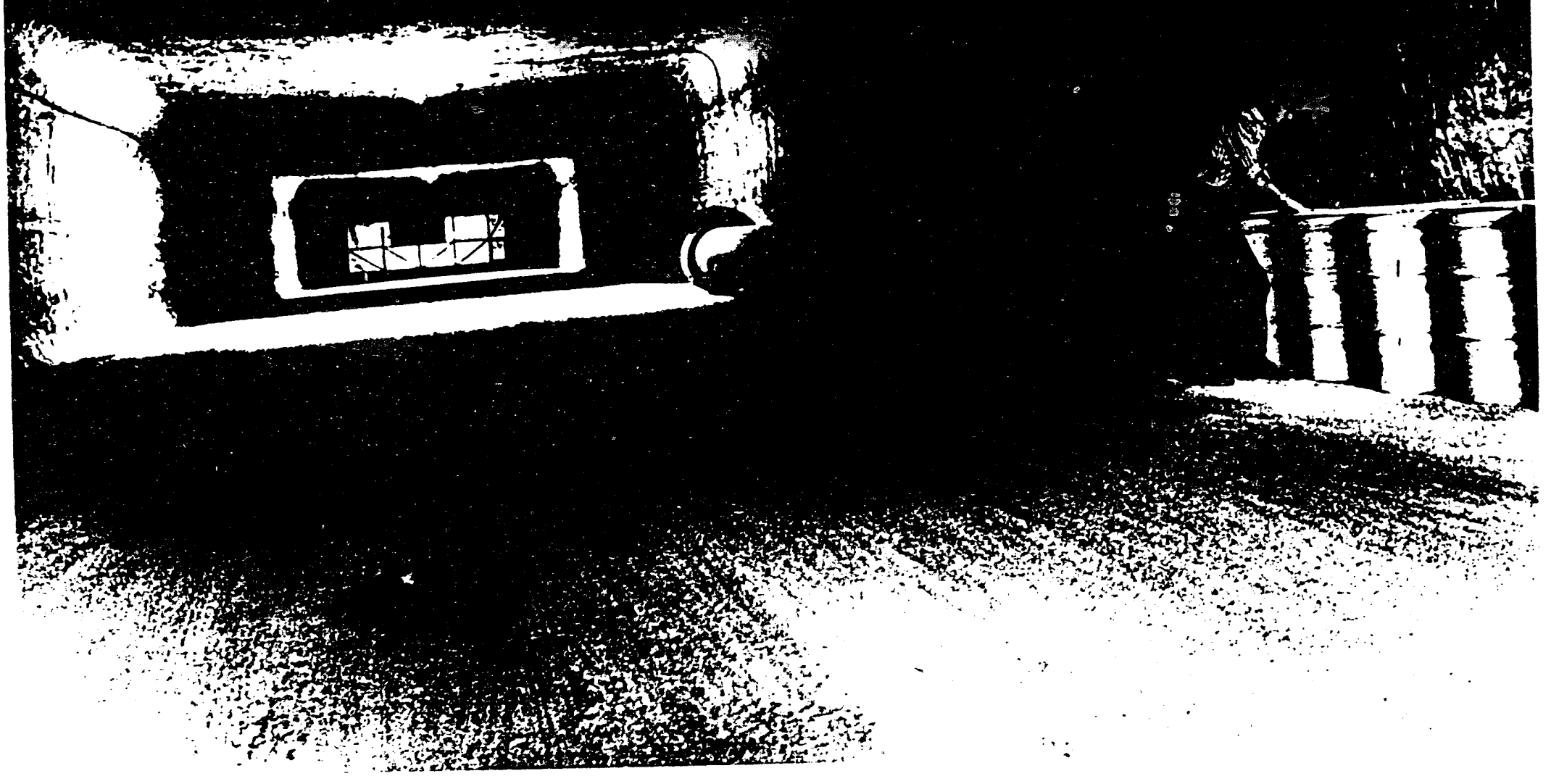


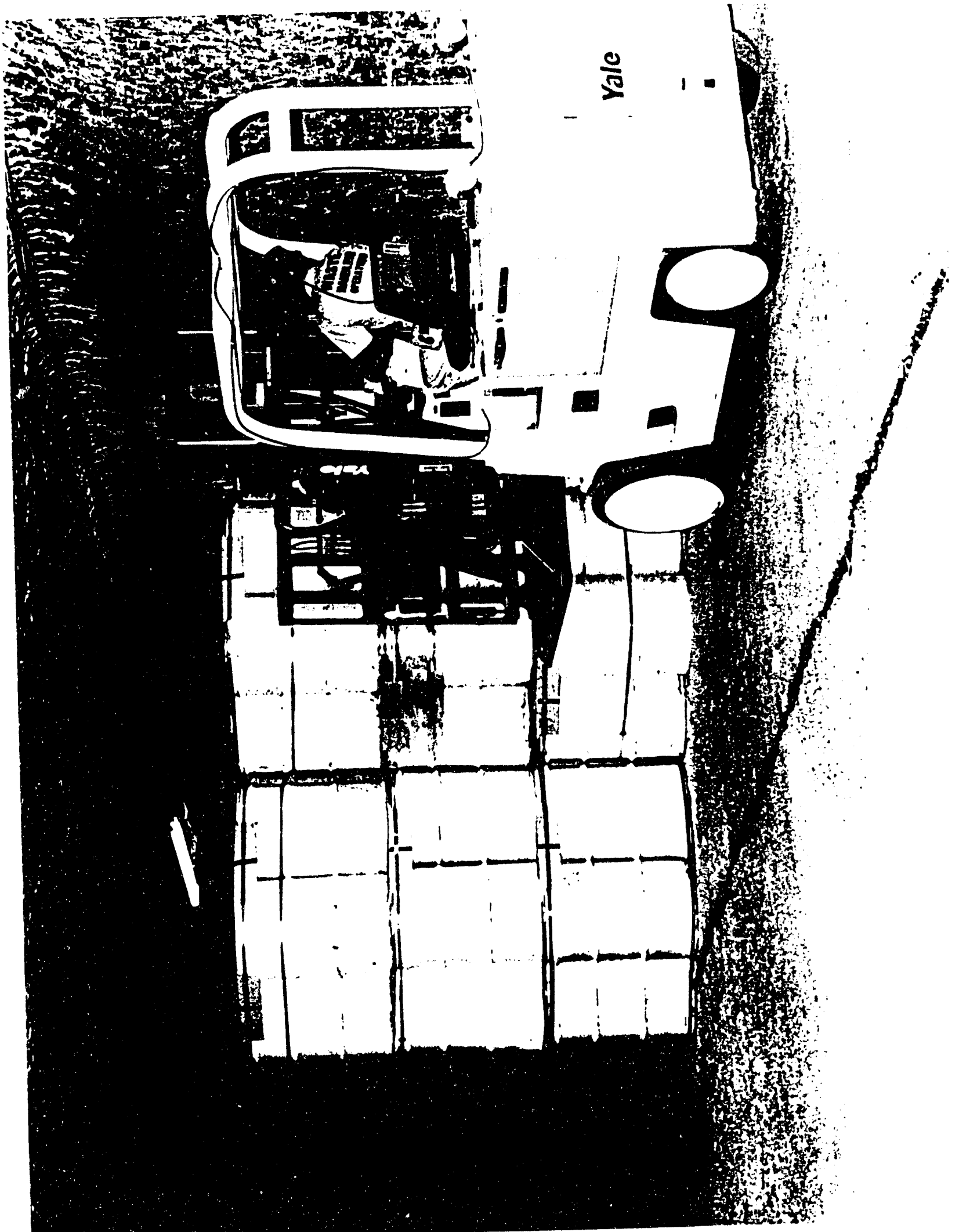


When WIPP was being constructed in 1983, four rooms were excavated for evaluation so officials could study such things as how fast salt would close the mined space. Instruments in the rooms measure how much the salt moves, or creeps each year.

The test rooms have been closed to all personnel since 1989. The roof fell in the first room February 4, 1991. That fall was an expected event. Engineers predict the roof will fall in the second room based on data from the 1991 fall and from remote interior monitoring, in early 1994.

According to the Annual Report to Congress (1990) the Office of Civilian Radioactive Waste Management (OCRWM) was established within DOE to implement the provisions of NWPA. The NWPA established the Federal policy for the management and permanent disposal of spent nuclear fuel from civilian nuclear power reactors and highlevel radioactive waste from the Nation's defense programs. To finance the waste management program, the NWPA established the Nuclear Waste Fund, which is composed of payments by the generators and owners of the waste. The NWPA included provisions for ensuring the participation of States, affected Indian Tribes, and the public in the program, and it prescribed both a schedule and a process for siting two geologic repositories, authorized the construction of one repository, and mandated the development of a transportation system for the waste.

The Amendments Act, enacted on December 22, 1987, made significant changes to the NWPA relating to repository siting and MRS and added new provisions for the establishment of several institutional entities with which OCRWM was to interact.

The OCRWM's mission and objectives is the responsibility for disposing of the Nation's spent nuclear fuel and HLW in a manner that protects the health and safety of the 
public and the quality of the environment. Although embodied in the Federal repository program that began with studies in the late 1950s, this mission was explicitly established by the NWPA and reaffirmed by the Amendment Act.

To direct the implementation of its mission, OC $\overline{\mathrm{C}} \mathrm{RWM}$ has established the following objectives:

1. Safe and timely disposal: to establish as soon as possible the ability to dispose of radioactive waste in a geologic repository licensed by the NRC.

2. Timely and adequate waste acceptance: to begin the operation of the waste management system as soon as practical in order to obtain the system development and operational benefits that have been identified for the MRS facility.

3. Schedule confidence: to establish confidence in the schedule for waste acceptance and disposal such that the managenient of radioactive waste is not an obstacle to the nuclear energy option.

4. System flexibility: to ensure that the program has flexibility necessary for adapting to future circumstances while fulfilling established commitments.

To achieve these objectives, OCRWM is developing a waste management system consisting of a geologic repository for permanent disposal deep beneath the surface of the earth, a facility for MRS, and a system for transporting the waste.

The development of the waste management program for nuclear waste storage, transportation, and disposal is a complex and unique program. It poses the unprecedented technical challenge of demonstrating the expected performance of a repository for 
thousands of yaars into the future. Also, there is the challenge of maintaining technical excellence while responding to the problems posed by accumulating wastes and, given the priority of technical excellence, conducting the program cost-effectively.

The demonstration of acceptable performance will be required in order to obtain a license from NRC, which has never before licensed a geologic repository. DOE, for its part, has never submitted and defended a license application; nor has DOE ever developed and implemented an NRC-regulated quality assurance program. In addition, the repository licensing process will entail the application of requirements that have not been previously adjudicated.

The program is made more complex by the involvement of a wide variety of affected and interested parties with different views and goals. These parties include the public and its elected representatives; affected States, units of local government, and Indian Tribes; the electric utilities, their rate-payers, and the rate-setting bodies; Federal agencies: and the scientific community participating as represented in the program. Ensuring that these parties are fully informed and enabled to exercise their roles is a continuing challenge.

The DOE Weapons Complex and the resulting external relations are handled by OCRWM and The Nuclear Waste Technical Review Board (NWTRB), which was also established by the NWPA, as amended. NWTRB has been in operation since March 1989 (Annual Report to Congress, 1990).

The NWTRB submitted its first report to the U.S. Congress and the Secretary of Energy in March 1990. NWTRB stated that its recommendations were made "to aid DOE in its effort to improve technical work being conducted at the site, to assist DOE in its 
overall study plan, and to advise Congress and the Secretary of Energy on regulatory or legislative areas of potential future concern."

DOE has developed an automated database management system to organize and track issues resulting from NWTRB interactions. With the automated system, DOE is able to track NWTRB's observations and recommendations, and to develop responses to be discussed with NWTRB. DOE provides information to NWTRB as requested and is considering recommendations that have resulted from DOE-NWTRB interactions.

The NWTRB also interacts with other Federal Agencies; which include: NRC, the Environmental Protection Agency (EPA) and the National Academy of Sciences (NAS).

\section{Relevance to Current Study}

Stovic, Flynn, \& Layman (1991) studied the perceived, trust, and the politics of nuclear waste. The DOE's program for disposing of HLW has been impeded by overwhelming political opposition fueled by public perception of risk. Analysis of these perceptions showed them to be deeply rooted in images in fear and dread that have been present since the discovery of radioactivity. The development of nuclear weapons linked these images to reality and the mishandling of radioactive wastes from the nation's military weapons facilities has contributed toward creating a profound state of mistrust that cannot be erased quickly or easily. Postponing the permanent repository and employing dry-cask storage of wastes on site would provide the time necessary for difficult social and political issues to be resolved.

There are many 'public interests' in the waste management program, and OCRWM interacts with a variety of organizations and individuals who have an interest in the 
program. The primary goals of OCRWM's public infoniation and outreach programs are to provide opportunities for public involvement, to provide complete and accurate information about the program, and to support the long-term efforts for waste management education.

The primary vehicles for public involvement in the program are public meetings and hearings that provide opportunities to comment on program documents. To this end, project update meetings and widely-advertised informal meetings are held every six months.

OCRWM conducts an active public information and outreach program. It maintains information offices in Beatty and Las Vegas, Nevada, where a diverse range of publications, videos and exhibits are available. Also provided was INFOLINK, a computerized bulletin board and communication network available to individuals or groups interested in the ORCWM program. INFOLINK accesses and provides information and is capable of conducting searches. Moreover, it has an Alert/News Flash feature that identifies and presents the latest information on new program developments and DOE positions on waste management issues. The full text of OCRWM press releases, selected speeches and technical papers, Congressional testimony, and the current OCRWM Bulletin are accessible in INFOLINK. Users may also o:der OCRWM publications through the system. The system is available free to anyone who wishes to use it and has communications compatibility.

OCRWM provides a much needed public awareness through the education process. The OCRWM will also benefit from this education process. In order to sufficiently implement the NWPA requirements, OCRWM will have a sustained need for personnel from a broad range of science-based disciplines for many years. The waste- 
management program will need the involvement of significant numbers of trained scientists and engineers in determining the suitability of sites, constructing and operating a repository, and developing a safe and efficient transporting system. OCRWM is actively implementing programs to ensure that it continues to have the vital human resources needed to support its multifaceted technical and scientific activities well into the next century.

In addition to realizing the benefits of DOE department-wide science education initiatives, OCRWM is also supporting its own efforts through the implementation of specific activities. OCRWM initiatives focus on educational activities beginning with children in kindergarten and continuing through graduate school.

OCRWM is supporting general science literacy in grades $\mathrm{K}$ through 12 through the development of specialized curricula within existing scientific programs. These curricula are designed to enhance scientific problem-solving skills and increase understanding of the HLW management program. The elementary educational curriculum will focus on providing students in grades 4 through 8 with objective, factual information about nuclear waste.

At the secondary school level, OCRWM is developing a four-unit curriculum for teachers of science and social studies in grades 8 through 12 that complies with State curricula guidelines and presents information on the source, volume, and nature of nuclear waste and discusses processes for its management and disposal. The four-unit curriculum, "Managing Our Nation's Nuclear Waste," covers nuclear waste issues and risk, sources and characteristics of nuclear waste, ionizing radiation, and the integrated wastemanagement system. 
At the university level, "Radioactive Waste Issues for the Non-Science Major" was developed and pilot tested during the 1989-90 academic year with 150 non-science majors at Hope College in Michigan. It is currently part of the approved curriculum. This course approaches radioactive waste management as both a science and a policy issue. The curriculum will increase awareness of university students to radioactive waste issues as well as educate tomorrow's decision makers and scientists about the technical and policy issues surrounding radioactive waste management.

The OCRWM graduate school fellowship program supports highly capable students in one or more of the following academic areas related to the management of spent fuel, HLW, and TRU waste; nuclear engineering, health physics, environmental engineering, geology, chemistry, and radiation sciences.

As part of the program, fellows are required to spend a minimum of three months at DOE Headquarters, a DOE laboratory, or the Yucca Mountain Site Characterization Project Office or another DOE-approved site. This experience provides the fellows access to on-going Research \& Development programs and allows them the opportunity to interact with DOE and DOE contractor scientists and engineers. The program is also designed to encourage universities to support and improve research activities and academic programs related to the management of spent fuel, $\mathrm{HLW}$, and TRU waste.

The University of Nevada at Las Vegas (UNLV) has obtained a Supercompactor to be used for educational activities as well as to support Federal agencies such as DOE. The UNLV plans to devote a percentage of its computer time to research in engineering, computing, mathematics, physics, chemistry, biology, and social studies. 
OCRWM's educational initiatives also include teacher accreditation workshops and cooperative agreements with various civic, public and international organizations to develop basic information about the program. Efforts underway to improve teacher skills include: the Nevada Science Project; In-service/Graduate Credit Workshops; the Earth and Space Science Summer Institute; presentations at Professional Society Meetings; the preparation of Clearinghouse/Directory of information and the provision of resources for Nevada School Media Centers. In addition, the OCRWM Speakers Bureau is available to provide in-person presentations to technical and professional organizations and groups.

OCRWM's international education activities include hosting and managing of the 1990 meeting of the Organization for Economic Cooperation and Development (OECD)/NEA High-Level Radioactive Waste Public Information Working Group. The meeting included general sessions involving a panel discussion of waste management programs of member countries, discussions with members of the University of Nevada System, participation in the American Nuclear Society's (ANS) in-service workshop for high school teachers in cooperation with UNLV and tours of Yucca Mountain and the Yucca Mountain Site Characterization Project Office.

OCRWM's educational outreach activities include an extensive array of traveling exhibits, speaker programs, publications and videos, and a computerized bulletin board. The exhibits provide an overview of the integrated waste-management system. The exhibit showings are presented at professional society meetings, educational institutions, and public meetings. This is a start in the right direction to educating the public to problems at hand.

The NWTRB has generally presented a positive assessment of the quality of scientific investigations performed by DOE and it contractors. 
The current study examines similar issues. The project studies the public and technical communities' perception of the risk involved with temporary, MRS, and permanent nuclear HLW and TRU waste storage repositories. The development of the waste management system for nuclear HLW and TRU waste storage, transportation, and disposal is a complex undertaking that poses the unprecedented technical challenge of demonstrating the expected performance of a repository for thousands of years into the future. 


\section{CHAPTER THREE -- RESEARCH DESIGN}

The purpose of this project is to study the public and technical communities' perception on the risk involved with temporary, MRS, and a permanent nuclear waste storage repository. It is believed that the public and technical communities see the nuclear HLW and TRU problem from two entirely different perspectives. This study is an effort to provide quantitative research data to support the hypotheses that follow.

\section{Hypotheses}

H1: The better our technical community takes care of nuclear HLW and TRU waste, the more crimfortable the residents feel.

$\mathrm{H} 2$ : The longer we wait to decide on a permanent repository for nuclear HLW and TRU waste, the higher the risk of an accident during temporary storage at the present facilities.

H3: With the track record of government in the nuclear field, the public no longer trusts their nuclear HLW and TRU waste management plans.

\section{General Methodology}

The current research project is a combination of opinion polling and the survey research methods. Not all of the variables could be strictly controlled and manipulated. A closed end survey was used to gather the data. The respondents have five options to select for their answers. Correlations are calculated from the survey statements that determine whether the hypotheses are supported or not. Even though a cause and effect 
relationship are predicted with the hypotheses, both independent and dependent variables rely in the self support of respondents for results.

\section{Specific Procedures}

The researcher developed a survey to gather data. The survey was developed to eliminate bias, and to relate to the hypotheses. The statements were not tested for statistical reliability. The survey consists of 25 statements with a brief introduction for the participants in the study on the management of nuclear High-Level Waste (HLW) and Transuranic (TRU) waste storage. The survey contained a cover letter explaining that research is being conducted at Colorado Christian University. The cover letter did not give the details of the study so the respondents were less likely to be led to answer the survey according to the researcher's beliefs.

On the survey the respondents were asked to respond to statements on the management of nuclear HLW and TRU waste storage. The current research project was designed to measure correlations between the technical community and the general public's perception of the risk involved in temporary, MRS, and a permanent nuclear waste storage repository.

To measure the confidence level in the existing technology associated with nuclear HLW and TRU waste storage a five point scale was used: $1=$ strongly agree, $2=$ agree, $3=$ unsure, $4=$ disagree, $5=$ strongly disagree.

The surveys were distributed to the Nuclear Safety Engineering (NSE) department at EG\&G Rocky Flats. Permission for distribution of the surveys was obtained from the Director of NSE before the research began. The surveys were also distributed to students 
in the MHR 86 class at Colorado Christian University in Lakewood Colorado. The students were allowed the time to complete the surveys during breaks. Another sample of the distribution was to survey everyone on a city block in Arvada, which is located within ten miles of the Department of Energy's (DOE) Rocky Flats Plant.

\section{Research Population/Sample}

The participants for the study consisted of individuals with technical backgrounds and people normally referred to as the general public. The general public for the most part consisted of everyone on a city block in Arvada. Also, some of the respondents were involved in undergraduate management courses at Colorado Christian University in Lakewood, Colorado. The participants ranged in age from 16 to 50 and older with most of the participants in the 31 to 50 range. Of the participants 38 were male and 18 were female. The lowest grade completed was 11 and the highest $16+$, with 33 being at least college graduates. The population for the study was selected by convenience or accidental sampling. Therefore, a nonprobability sampling method was used.

\section{Data Collection}

One sample of the surveys was distributed to the entire staff in the Nuclear Safety Engineering (NSE) department at EG\&G Rocky Flats Plant, which is owned by the Department of Energy (DOE). The NSE department works staggered hours Monday through Friday from 6:30 A.M. to 5:30 P.M. The surveys were distributed March 11, 1994 through the department mail drops. The surveys were designed so that all the participant had to do upon completion was fold, staple, and drop the survey in the department mail. 
The second set of surveys was distributed to the students in MHR 86 class at Colorado Christian University. The surveys were distributed March 14, 1994 at the beginning of class. The survey contains a brief introduction and no other information was provided in order to minimize bias. The surveys were completed during class breaks and collected at the end of class. It was estimated that the surveys took ten minutes to complete.

The last set of surveys was distributed on West 66th Place in Arvada Colorado, which is located within ten miles of DOE's Rocky Flats Plant. The surveys were placed in the mail on March 14, 1994 and the surveys were designed so that all the participant had to do upon completion was fold, staple, and drop the pre-stamped survey in the U.S. mail.

An approximate total of 100 surveys was distributed and 56 were returned. This represented a $56 \%$ response to the questionnaire. The researcher offered to share the results with any participant who provided the researcher with a self addressed envelope. Explanations were given that the results would be used for course requirements only. The researcher was completing a college course which required a research project. The participants were assured that the results would be kept confidential. They were for the research project only and would not be sold, formally published, or used in any way that would violate the privacy of the participants. However, the participants were told that the completed project would be bound and would become part of the Colorado Christian University library, although no names or other means of identification were employed on the survey. If the participants did not want to complete the survey based on this information, they could decline. 


\section{Treatment of Data}

The significance level for the current study was set at 3.5 or more, 2.5 or less and $75 \%$ or more when required. The hypotheses required a multiple set of significance levels in order to measure the correlations.

Hypothesis one, the better our technical community takes care of nuclear HLW and TRU waste, the more comfortable the residents feel, was measured by a five point scale with the more comfortable the residents feel measured by $1=$ strongly disagree, $2=$ disagree, $3=$ unsure, $4=$ agree, and $5=$ strongly agree.

Analyses were completed by multiplying the number of responses by the numerical value of the response and dividing by the total number of responses.

Hypothesis two, the longer we wait to decide on a permanent repository for nuclear HLW and TRU waste, the higher the risk of an accident during temporary storage at the present facilities, was measured by a five point scale with the higher the risk of an accident during temporary storage at the present facilities measured by $1=$ strongly disagree, 2 = disagree, $3=$ unsure, $4=$ agree, and $5=$ strongly agree.

Analyses was completed by multiplying the number of responses by the numerical value of the response and dividing by the total number of responses.

Hypothesis three, with the track record of government in the nuclear field, the public no longer trusts their nuclear HLW and TRU waste management plans, was measured by a five point scale with the public no longer trusts the governments nuclear HLW and TRU waste management plans, measured by 1 = strongly disagree, 
$2=$ disagree, 3 = unsure, $4=$ agree, and $5=$ strongly agree.

Analyses were completed by multiplying the number of responses by the numerical value of the response and dividing by the total number of responses.

There were three hypotheses represented on a survey in statement form and presented to the population in NSE department at EG\&G Rocky Flats, students of the MHR 86 class at Colorado Christian University in Lakewood, Colorado and to the residents on West 66th Place in Arvada Colorado. The results are presented in the next chapter. 


\section{CHAPTER FOUR -- FINDINGS}

\section{Problem Statement}

The problem being studied for this project is the public and technical communities' perception on risk of nuclear HLW and TRU storage. Nuclear HLW and TRU waste are primarily generated from commercial power reactors and weapons facilities. Because of poor risk management by the Department of Energy (DOE) and Nuclear Regulatory Commission (NRC), the public feels like victims rather than beneficiaries of the technology created by the science and engineering community.

The scope of the project will involve the following issues. If the technical community handles nuclear HLW and TRU in a safe manner, then the local residents, as well as the ones in the next state will feel comfortable with the long term storage in their back yard. This brings up a second issue. The longer we wait while deciding on a permanent repository for nuclear HLW and TRU waste, the higher the risk of an accident during temporary storage. This increases the risk of an accident while exposing a larger area of the country to that possibility. A Monitored Retrievable Storage (MRS) amounts to an interim storage facility until a permanent nuclear HLW and TRU waste repository can be implemented. The third is the belief that with the track record of government in the nuclear field, the public no longer trusts their nuclear HLW and TRU waste management plans.

While finding a permanent repository site for nuclear waste is one of the most urgent energy problems at the national and world levels, finding a site has drug on for decades without a successful resolution. With present technology the problem appears to be as much political as technical. From past studies it is obvious that the public does not 
like nuclear waste. Another problem that affects public perceptions of risk is the record of federal mismanagement of radioactive wastes at the nation's military weapons facilities. According to the National Academy of Sciences (1989), leakage from these facilities has caused widespread environmental contamination, the cleanup of which is projected to cost more than $\$ 150$ billion over the next 30 years. Moreover, the recent revelation that Hanford, Washington, weapons plant released unprecedented amounts of radiation in the 1940s and 1950s will certainly compound the negative imagery associated with the nuclear waste repository and further undermine public trust in government management of nuclear waste disposal.

\section{General Results}

Approximately 100 surveys were distributed to the population in the Nuclear Safety Engineering (NSE) department at EG\&G Rocky Flats, students of the MHR 86 class at Colorado Christian University in Lakewood, Colorado and to the residents on West 66th Place in Arvada Colorado.

One sample of the surveys was distributed to the entire staff in the Nuclear Safety Engineering (NSE) department at EG\&G Rocky Flats Plant, which is owned by the Department of Energy (DOE). The NSE department works staggered hours Monday through Friday from 6:30 A.M. to 5:30 P.M. The surveys were distributed March 11, 1994 through the department mail drops. The surveys were designed so that all the participant had to do upon completion was fold, staple, and drop the survey in the department mail.

The second set of surveys was distributed to the students in MHR 86 class at Colorado Christian University. The surveys were distributed March 14, 1994 at the 
beginning of class. The survey contains a brief introduction and no other information was provided in order to minimize bias. The surveys were completed during class breaks and collected at the end of class. It was estimated that the surveys took ten minutes to complete.

The last set of surveys was distributed on West 66th Place in Arvada Colorado, which is located within ten miles of DOE's Rocky Flats Plant. The surveys were placed in the mail on March 14, 1994 and the surveys were designed so that all the participant had to do upon completion was fold, staple, and drop the pre-stamped survey in the U.S. mail.

From the 100 surveys distributed, 56 were returned. Of the 56 surveys returned there were 38 completed by males and 18 by females. There was one survey completed by a high school student, three by high school graduates, 19 with some college, and 33 by college graduates or better. Additional data collected was whether each participant had a non-technical or technical background. Of the participants, 36 had technical and 20 had non-technical backgrounds. The following represents data on the age groups:

$\begin{array}{lc}\text { AGE } & \text { \# Participants } \\ 16-21 & 1 \\ 22-30 & 7 \\ 31-40 & 20 \\ 41-50 & 21 \\ 50 \text { or older } & 7\end{array}$

The researcher offered to share the results with any participate who provided the researcher with a self-addressed stamped envelope. After the completion of the survey, only one self-addressed envelope had been received. 
Explanations were given that the results were to be used for course requirements only. The researcher was completing a college course which required a research project. The participants were assured that the results would be kept confidential. They were for the research project only and would not be sold, formally published, or used in any way that would violate the privacy of the participants or the university. However, the participants were told the completed project would be bound and would become part of Colorado Christian University's library. Although, no names or other means of identification were employed on the survey. If the participants did not want to complete the survey based on this information, they could decline.

\section{Hypotheses}

H1: The better our technical community takes care of nuclear HLW and TRU, the more comfortable the residents feel.

H2: The longer we wait to decide on a permanent repository for nuclear HLW and TRU, the higher the risk of an accident during temporary storage at the present facilities.

H3: With the track record of government in the nuclear field, the public no longer trusts their nuclear HLW and TRU waste management plans. 


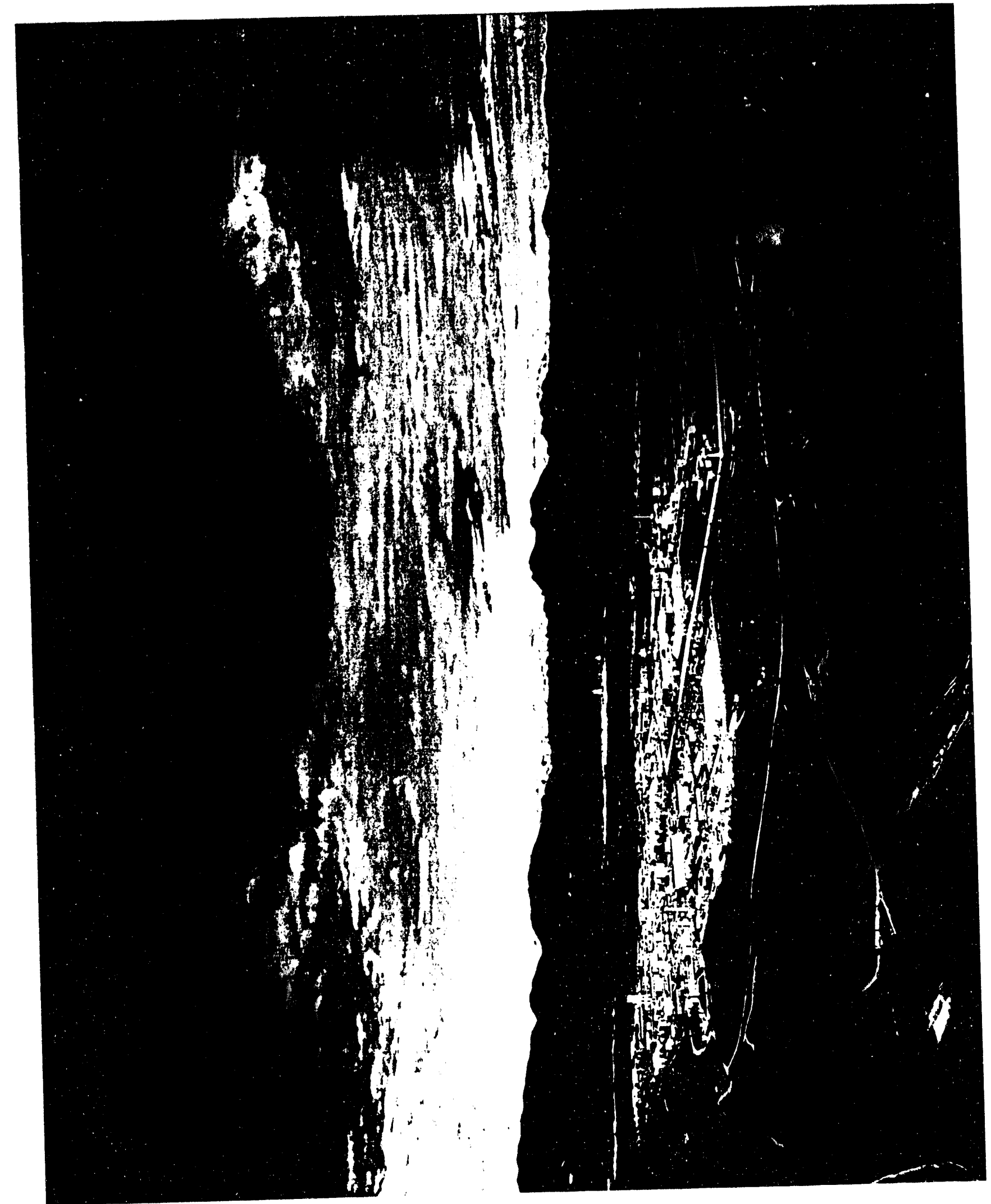




\section{Results}

\section{H1: The better our technical community takes care of nuclear HLW and}

TRU waste, the more comfortable the residents feel. Statements $5,8,11,12,16,23$, and 25 measured the positive responses to hypothesis one. The significance level was set

at 3.5 or more. The results showed a level of 4.63. The significance level was exceeded. Residents feel more comfortable when the technical community takes care of nuclear HLW and TRU waste.

Statement 24 on the survey measured the negative response to the hypothesis. The significance level was set at 2.5 or less. The results showed a level of 0.38 . The sigrificance level was exceeded. When the technical community does not take care of nuclear HLW and TRU waste issues, the residents are not comfortable.

The graph on the next page indicates that the actual results are within the yellow area that represents the hypothesized results. The hypothesis is supported since the actual results were within the yellow, hypothesized results area. 


\section{HYPOTHESIS \#1}

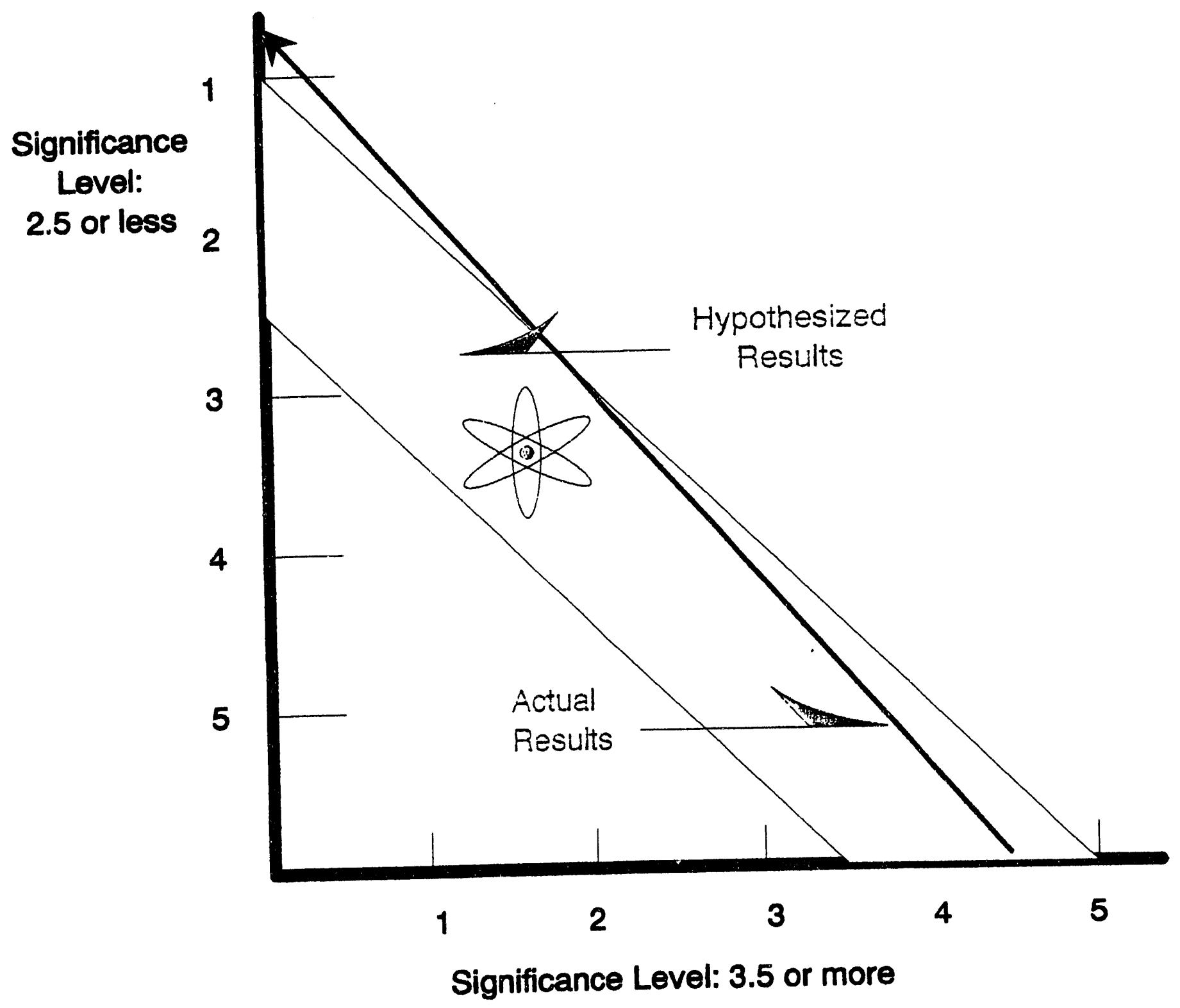

H1: The better our technical community takes care of nuclear HIW and TRU waste, the more comfortable the residents feel. 
H2: The longer we wait to decide on a permanent repository for nuclear

HLW and TRU, the higher the risk of an accident during temporary storage at the

present facilities. Statements 6 and 14 measured the positive responses to hypothesis

two. The significance level was set at 3.5 or more. The results showed a level of 1.28 .

The significance level was not met. The response indicated that temporary storage did not pose a higher risk.

Statements 9,10 , and 20 on the survey measured the negative response to the hypothesis. The significance level was set at 2.5 or less. The results showed a level of 2.01. The significance level was exceeded. The negatively worded statements indicated that a higher risk factor was involved with temporary storage of nuclear HLW and TRU waste.

The graph on the next page indicates that the actual results are not within the yellow area that represents the hypothesized results. The hypothesis is not supported since the actual results were not completely within the yellow, hypothesized results area. 


\section{HYPOTHESIS \#2}

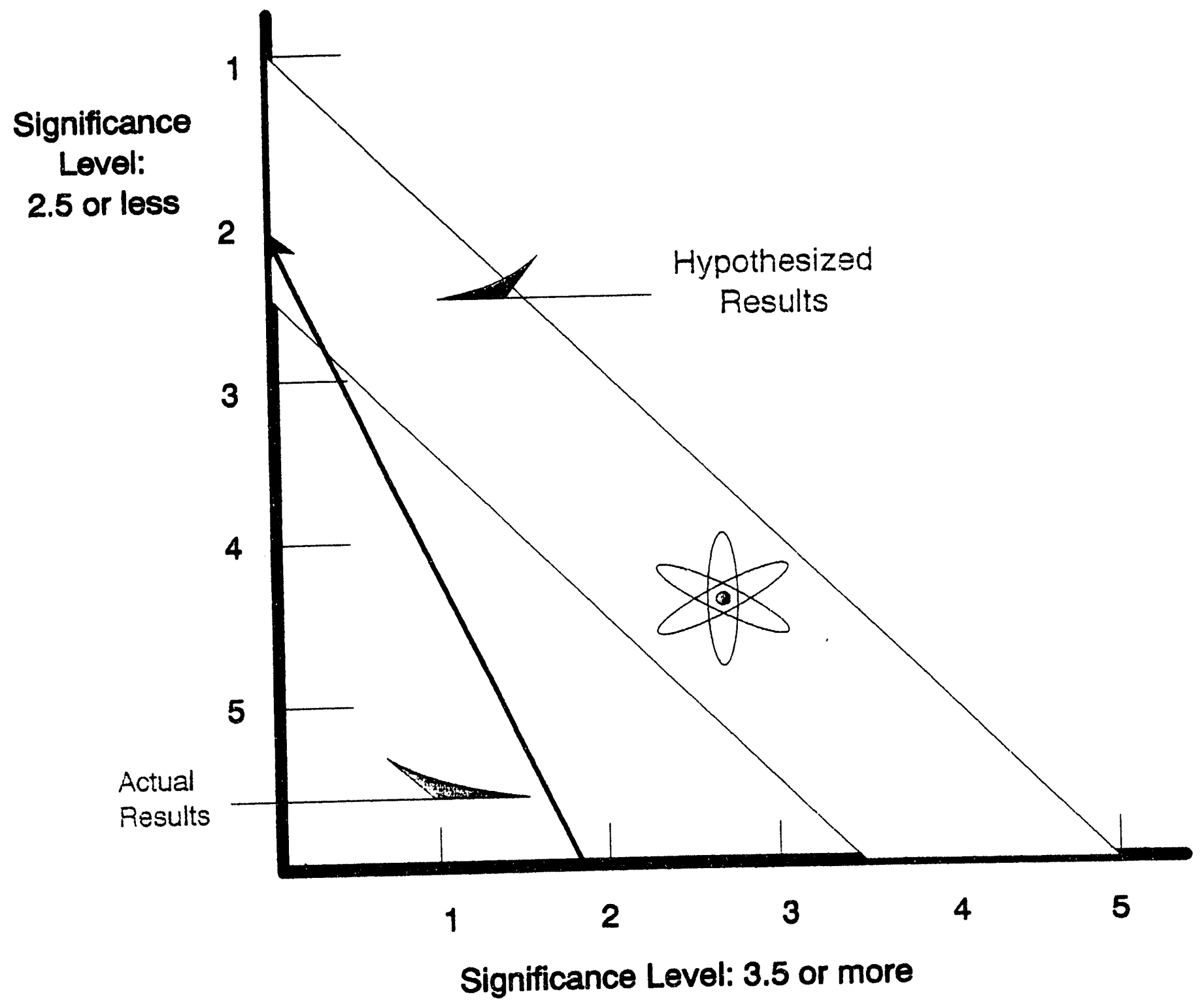

H2: The longer we wait to decide on a permanent repository for nuclear HLW and TRU, the higher the risk of an accident during temporary storage at the present facilities. 


\section{H3: With the track record of government in the nuclear field, the public no}

\section{longer trusts their nuclear HLW and TRU waste management plans. Statements 3,}

$17,18,19$, and 22 measured the positive responses to hypothesis three. The significance level was set at 3.5 or more. The results showed a level of 2.78 . The significance level was not exceeded. The results show that the public does exhibit trust in the governments nuclear HLW and TRU waste management plans.

Statements 13,15 , and 21 on the survey measured the negative response to the hypothesis. The significance level was set at 2.5 or less. The results showed a level of 1.92. The significance level was exceeded. The public does express some mistrust in the governments nuclear HLW and TRU waste management plan.

The graph on the next page indicates that the actual results are not within the yellow area that represents the hypothesized results. The hypothesis is not supported since the actual results were not within the yellow, hypothesized results area. 


\section{HYPOTHESIS \#3}

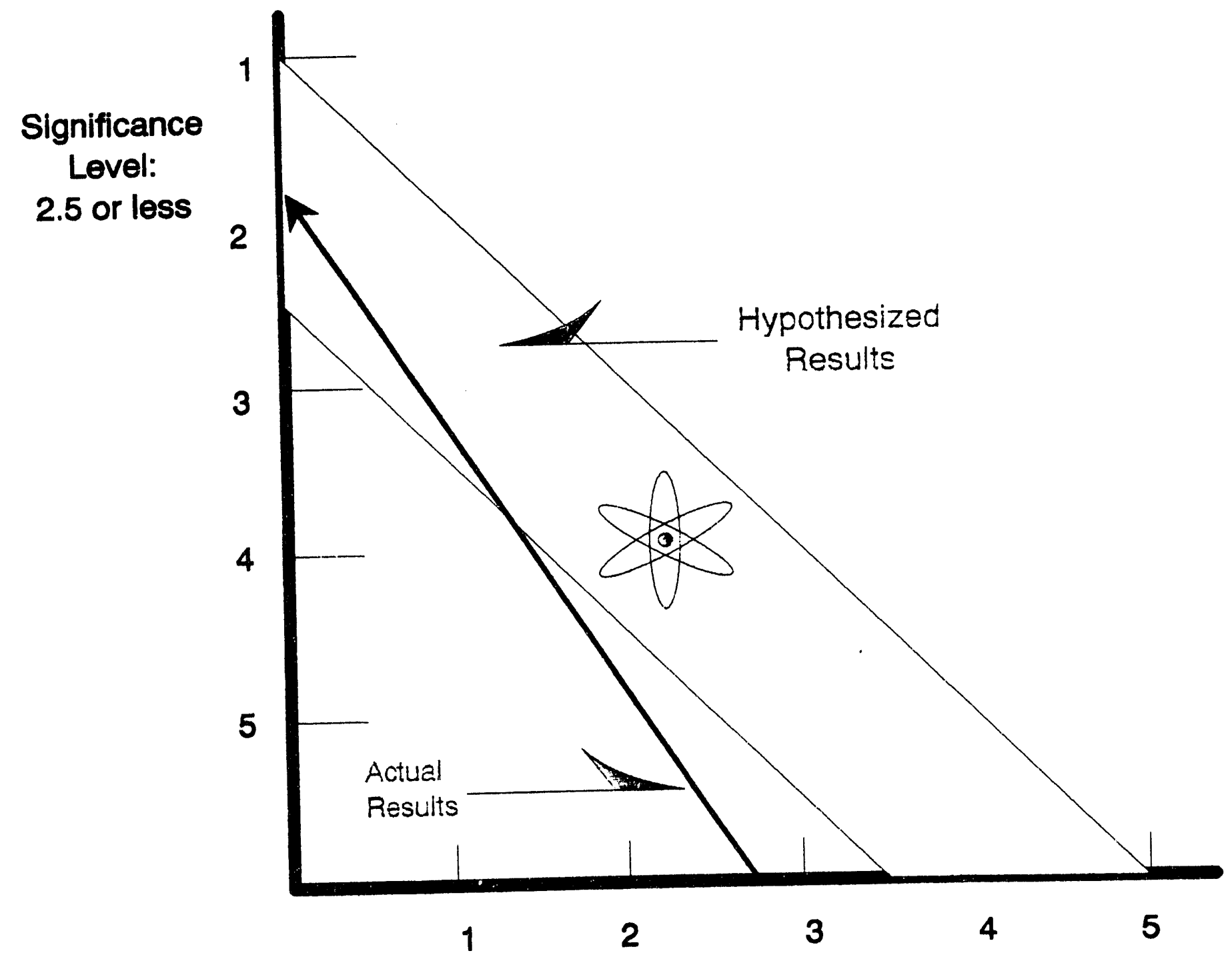

Significance Level: 3.5 or more

H3: With the track record of government in the nuclear field, the public no longer trusts their nuclear HLW and TRU waste management plans. 


\section{Summary}

The better our technical community takes care of nuclear HLW and TRU waste, the more comfortable the residents feel. The results show that the local communities are more comfortable when the technical community takes care of nuclear HLW and TRU waste.

The longer we wait to decide on a permanent repository for nuclear HLW and TRU waste, the higher the risk of an accident during temporary storage at the present facilities. However, the results indicate that they draw a wide range of conclusion based on their limited knowledge.

With the track record of government in the nuclear field, the public no longer trusts their nuclear HLW and TRU waste management plans. However, the results for hypothesis three also indicate that they draw a wide range of conclusions based on their limited knowledge. 


\section{CHAPTER FIVE - CONCLUSIONS}

\section{Conclusions}

\section{Conclusions Based on Findings}

It is concluded that in general, the public needs to be more informed in the nuclear field as a whole. One observation made by the researcher was that even highly educated individuals in the technical community were inconsistent with their responses to many of the questions on the survey. This indicated that the nuclear community and the government should become more pro-active in educating the public.

\section{Alternative Explanations of Findings}

The population surveyed for the study was comprised of respondents with some college or who were college graduates. Most of the participants were engineers, some nuclear engineers. It was surprising to the researcher that the results did not give any indication that the technical engineers were in any kind of agreement on the direction our nuclear HLW and TRU waste disposal policy should follow. This magnifies the seriousness of the problem our world faces over the next several decades.

\section{Limitations of the Study}

There were several limitations to the study. The population studied had only 56 participants. Most of the respondents had some college or were college graduates. Most of the participants were engineers, some nuclear engineers, and may have had a better understanding of the nuclear HLW and TRU waste problem. However, the results of the 
survey do not bear this out. A larger population size would have yielded results that were more conclusive by including a population with a more representative education spread. The results are generalized to the population studied and an assumption was made that if most college graduates are not aware of the nuclear HLW and TRU waste disposal problem, the less educated population would be even less aware. Any generalization beyond this is not advised.

Approximately $66 \%$ of the population worked at the EG\&G Rocky Flats Plant in Golden, Colorado. This $66 \%$ should have had a better understanding of the nuclear HLW and TRU waste disposal problem. The survey indicated otherwise. This may have biased the results if they had all responded to the survey in the same manner, but to the surprise of the researcher, that was not the case.

\section{Implications}

\section{Implications for Professional Practice or Decision Making}

While disposal deep within a geologic formation has dominated both scientific and policy discussions, other methods for disposing of nuclear HLW have been considered. The 1980 DOE Generic Environmental Impact Statement evaluated various disposal methods before designating geologic disposal as the preferred alternative.

The only other alternative that has been actively researched is disposal under deepsea sediments. In a program that began in 1973 in cooperation with several other countries, the United States investigated the feasibility of burying the waste packages in geologic formations beneath the deep-ocean floor. Research focused on certain areas in international waters (more than 200 miles from shore) in the western North Pacific and the 
North Atlantic. In these areas, the ocean is 3,000 to 5,000 meters deep, the sea floor is flat, and the sediments are thick and uniform over a large area. These areas are very stable geologically, isolated from the rest of the planet, and thought to be generally bereft of life. Sediments in these areas consist of extremely fine-grained clay that would be expected to absorb most of the radionuclides in the waste. These sediments are considered the primary barrier to the release of radionuclides into the biosphere. The depth of the ocean floor in these areas would pose a significant barrier to human intrusion.

Research thus far has not revealed any major flaws in the seabed concept, but important technical questions remain to be answered. These include: whether or not water flows through ocean sediments; if it flows, at what rate it moves; and what effect the heat generated by waste packages may have on the surrounding sediment. The U.S. research project planned to report on the feasibility of the subseabed concept in the 1990s. However, the program was terminated in 1986 by DOE.

The survey indicated that this was a wise decision by DOE. Public perception on ocean dumping was almost unanimously against that alternative.

The Organization for Economic Cooperation and Development (an organization of economically developed nations, including the United States, Japan, and countries in Western Europe) coordinated the international research program. In 1988 they found that subseabed disposal was technically feasible, but that before seabed disposal could actually occur, more research was needed to reduce technical uncertainty and an international system was needed to regulate and manage the disposal process.

Currently, the 1976 Convention on Prevention of Marine Pollution by Dumping of Wastes and Other Matter (also known as the London Dumping Convention and signed by 
most coastal nations) regulates ocean dumping of radioactive and hazardous waste. Although disposal within the seabed clay differs from ocean dumping on the ocean floor, member nations agreed that none of them should begin seabed disposal without further research and that, if a nation were to implement a program of seabed disposal, the London Convention could provide an appropriate international regulatory regime.

Several other suggested alternatives appear to be impractical. A proposal to bury canisters of nuclear HLW in the Antarctic ice sheet were abandoned because of uncertainty about the stability of the ice caps over thousands of years required for radioactive decay of waste. Similarly, although the idea of rocketing nuclear waste into space was ruled technically feasible by the National Aeronautics and Space Administration (NASA), it is no longer under investigation because the cost of such disposal and the risk of a launch accident are considered too high.

Some people argue that we can safely delay taking action on nuclear HLW disposal for 50 or more years while continuing to research alternative disposal methods. They recommend storing spent fuel rods in pools of water or in air-cooled above-ground casks or vaults and maintaining continuous human surveillance until the radioactivity and heat given off by the short-lived nuclides have decreased to more manageable levels. Sweden and France, for example, have incorporated long-term (15-30 years) storage as an element of their disposal plans, although they also are proceeding to develop geologic disposal.

Proponents to long-term disposal for the United States point out that such a plan would buy more time for the development of disposal options. Others, including some critics of the government's lack of progress on nuclear waste management, see this proposal as a delaying tactic. They say this country must develop a permanent solution 
now before making further commitments to nuclear power. They also argue that longrange temporary storage may become de facto permanent storage and that it is wrong to leave this problem for future generations to solve and finance.

\section{Implications for Future Research}

Future research should investigate several more issues. The current project did not investigate in detail how much the respondents in the survey actually knew about alternative methods of disposal. Some of the alternative methods sound unreasonable on the surface, but should be given more consideration, while some of them appear reasonable until you look at the facts.

In addition, more research should be performed to acquire a better understanding on the public perception on Monitored Retrievable Storage (MRS) facility. The MRS is a vital part of America's Civilian Radioactive Waste Management System, the National system to dispose of nuclear high-level radioactive waste. "Spent" or "used" fuel from commercial nuclear power plants currently is being stored safely in protected areas at the plants, but those storage spaces are rapidly reaching capacity. The MRS will temporarily store a limited amount of this used fuel in thick-walled, above ground engineered structures until it is shipped to a mined geologic repository for permanent disposal. The facility will provide additional, temporary storage until the repository is operational.

The MRS will be required to meet strict safety standards established and enforced by the NRC. Facility operations will be closely monitored to ensure the health and safety of the workers and the public. After its mission is completed, the MRS will be decommissioned and dismantled, and all radioactive materials will be removed so that the site can be released for unrestricted use. 


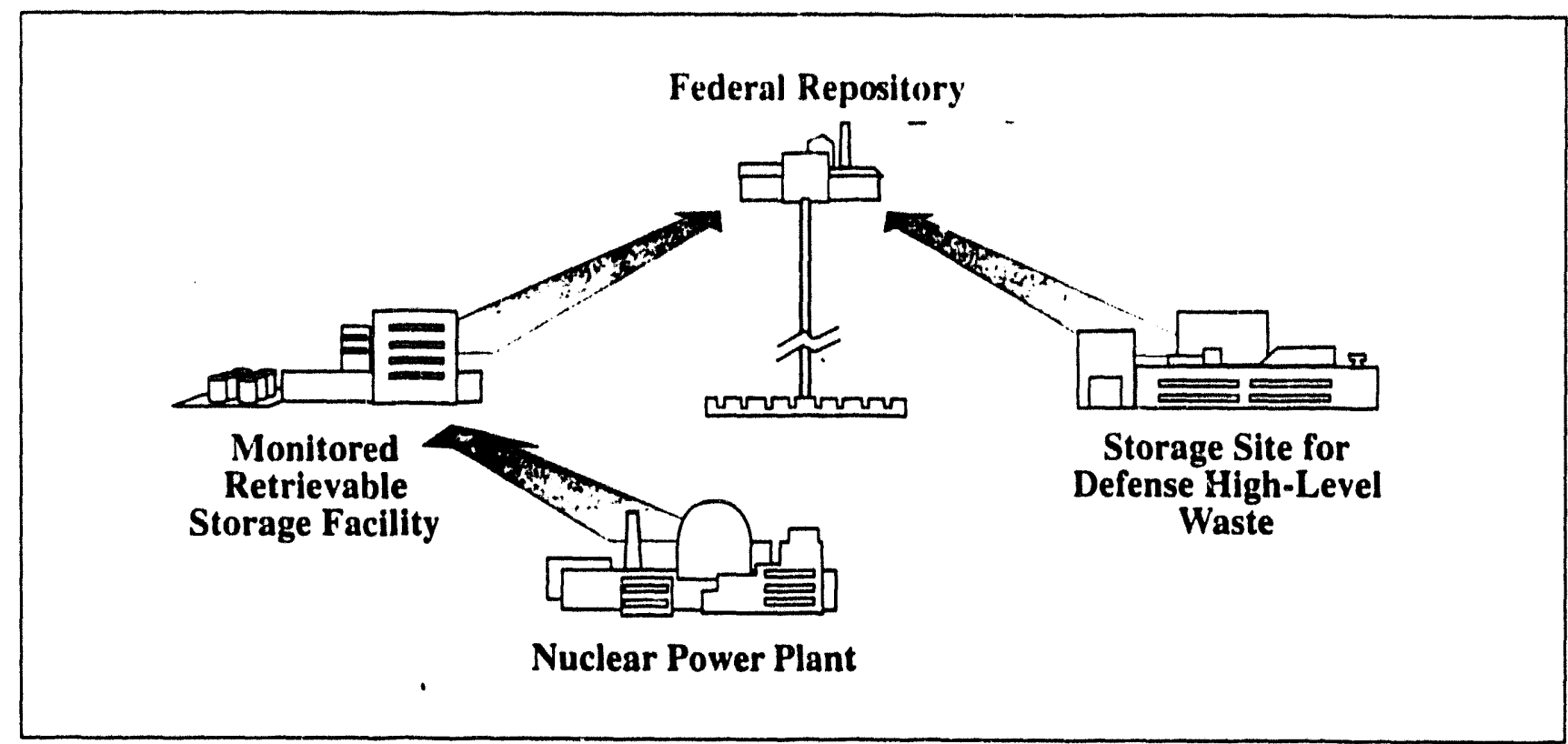

Spent muclear fuel will be shipped from nuclear power plants to the MRS, and from the MRS to the Fedcral repository.

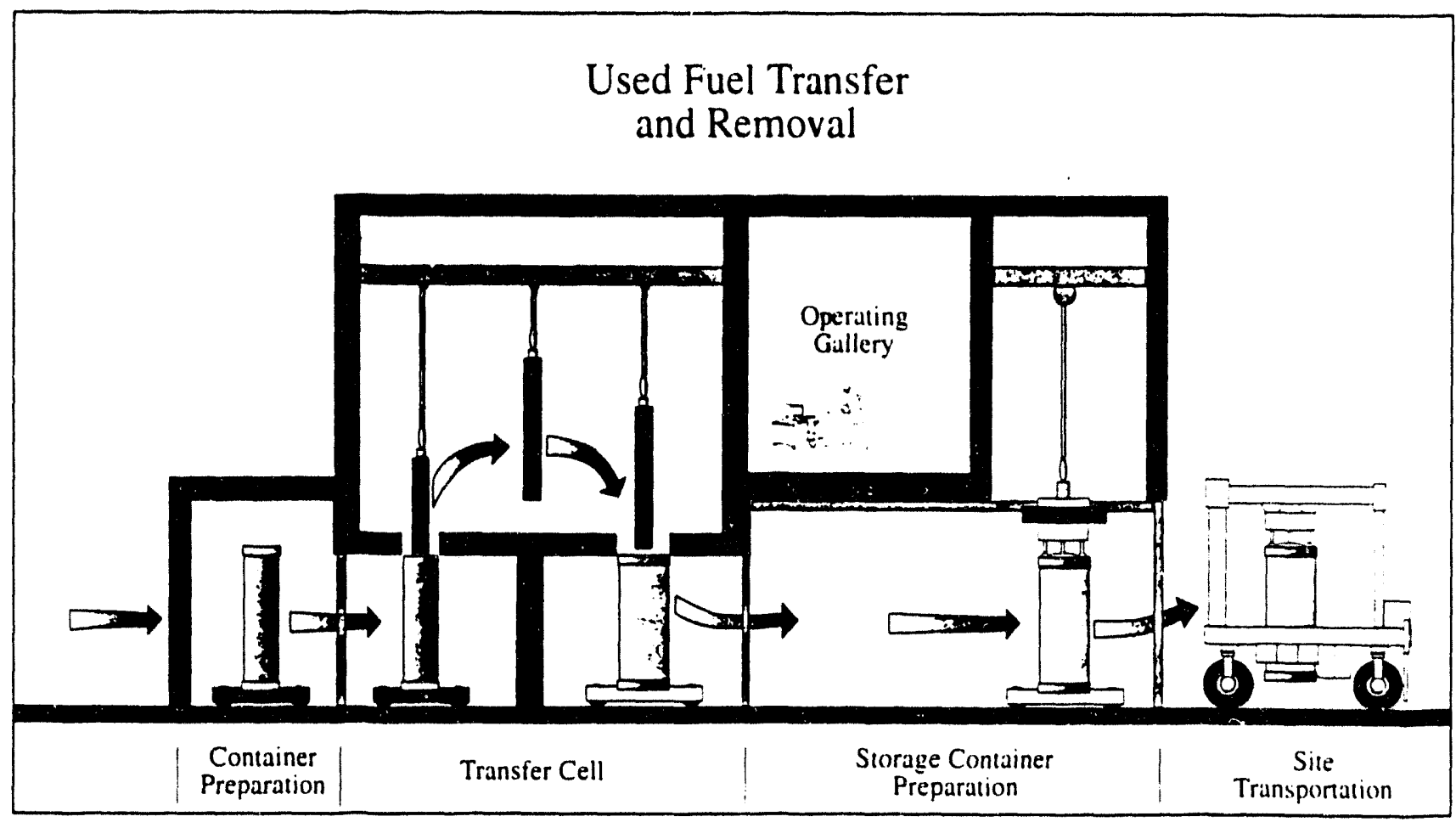

Inside the transfer facility, used fuel handling operations are efficient and safe. A shipping container is prepared for the transfer operation, then moved to a transfer cell where the used fuel assemblies are individually removed from the shipping container and placed in a storage container. The storage container is sealed and then placed on the site transporter that delivers it to the storage yard. 


\section{Recommendations}

\section{Recommendations for Policy Development}

Resolving issues and forging public policy on radioactive waste is difficult for many reasons. The responsibility for setting policy is widely dispersed among state and federal governments and agencies. And although much that is known about nuclear HLW and TRU waste can be called scientific fact, much else is far less certain. This makes for difficult decisions concerning policy.

No one can be an expert in all fields of science and technology that come into play in nuclear HLW and TRU waste management decisions. We all must rely on others for some information and judgments.

The strongest recommendation for an individual as a taxpayer, consumer of electric power, community resident, environmentalist, public health advocate, or concerned parent is, if there is an interest in nuclear HLW and TRU waste, the most likely issues for involvement are:

- The effort to site a HLW repository, now at Yucca Mountain, Nevada.

- The effort to site a central spent fuel storage facility, now called a MRS facility.

- Decisions about whether and how to expand spent fuel storage capacity at reactors.

- Cleanup of sites contaminated by weapons production.

- Development of a new system for disposing of defense waste, including siting new facilities and redefining the use of existing facilities. 
The best way to be involved is to become informed. Congress was explicit in the 1982 Nuclear Waste Policy Act about the importance of public participation in decisionmaking on HLW management. The act states that "States and public participation in planning and development of repositories is essential in order to promote public confidence in the safety of disposal of such waste and spent fuel." However, while the act cites many specific requirements for state and tribal participation, the opportunities for more general public participation are not so clearly described. Furthermore, the 1987 amendments foreclosed some avenues by limiting site consideration to Yucca Mountain, Nevada.

To obtain general information about nuclear $\mathrm{HLW}$ and TRU waste issues:

- Begin with additional background reading.

- Ask to be on the mailing list of the agency responsible for your areas of concern: the Department of Transportation (DOT), the Environmental Protection Agency (EPA), the Nuclear Regulatory Commission (NRC), the Department of Energy (DOE Headquarters in Washington, D.C., for general policy issues, and MRS; Nevada Field Office for repository issues).

- Join an organization that monitors and reports on development in nuclear HLW waste management, or form your own.

- Monitor the Federal Register or stay in touch with organizations that do. The Federal Register contains notices of executive branch and regulatory agency meetings and rulemakings, proposed regulations, information on hearings and comment periods, contacts for additional information, final regulations, and effective dates. The Register is published daily and is available from libraries and the U.S. Government Printing Office. 
- Contact your members of Congress and ask to be kept informed about pending legislation or hearings.

- Take a position on issues of concern to you and work to build grassroots support for their adoption by decision makers. Join a local or national organization that shares your interests -- or form a group to help you with the study, analysis, and monitoring that will lead to effective participation.

- Write letters to editors, or write op-ed pieces for your local newspaper.

- Respond to opportunities to comment orally or in writing on NEPA environmental documents, proposed rules or regulations, or NRC licensing proceedings.

To find out more about the HLW repository program:

- Ask to be on the mailing list for the monthly publication, Office of Civilian Radioactive Waste Management Bulletin, by writing or calling the Civilian Radioactive Waste Management Information Center. Staff at the Information Center can supply material and answer questions about the Civilian Radioactive Waste Management Program. Access to INFOLINK, a computerized database of current information on the program, is also available through the information center.

- Visit or contact one of the DOE's Public Information Offices (in Las Vegas and several other locations). These offices answer inquiries and comments about the repository program. The offices also have libraries and exhibits that are open to the public.

- Visit the Yucca Mountain facility. DOE conducts regular public tours, which include opportunities to speak with scientists and engineers working at the site.

- Write or call the state of Nevada's Nuclear Waste Project Office. The Office responds to comments and questions relating to the repository, and, upon request, provides speakers or organizes panel discussions among representatives from various interest groups. Ask to be on the mailing list for the state of Nevada's monthly newsletter. 
To stay informed abour the Waste Isolation Pilot Plant (WIPP) near Carlsbad, New Mexico and to be involved:

- Contact New Mexico's watchdog Environmental Evaluation Group and ask for a list of publications and be put on their mailing list.

- Contact the Board on Radioactive Waste Management of the National Academy of Sciences and ask for a list of reports from their panel on WIPP. Watch for announcements about meetings of the panel in your area and attend the public sessions.

- Contact EPA for information about the agency's plans for carrying out its regulatory responsibilities for WIPP. Attend EPA meetings and hearings and comment on issues that concern you.

- Contact DOE and ask to be put on the mailing list for information about WIPP.

- Join local and national interest groups that have followed the development of WIPP.

The siting, construction, and operation of facilities for the disposal or storage of nuclear HLW and TRU waste may have many significant effects on communities, public and worker health, the environment, and the local and national economies. Similarly, the delay or failure to provide safe and permanent disposal sites may adversely affect the communities in which waste is now in temporary storage--in facilities that were never intended for such long-term use. Thus, it is important not only that citizens have roles in deciding how things will be done, but also that they contribute to the process of making things happen, addressing significant problems rather than delaying action indefinitely. Deciding when action is called for is sometimes the most difficult decision. Those who have faith in the democratic process believe that the public will help ensure that the right decisions are inade about how and when to act. 
By becoming involved, you can help shape the ground rules--key management plans, strategies, and regulations--and thus help ensure effective and equitable policies in the future.

\section{Recommendations for Professional Practice}

Disposal of waste in stable geological formations that are isolated from appreciable contact with ground water appears to provide adequate assurance against escape of consequential amounts of radioactivity even over long periods of time.

Current federal policy on nuclear HLW disposal calls for building at least one geological repository to house the nation's HLW permanently. Congress in 1987 directed DOE to confine its siting investigations for this facility to Yucca Mountain, Nevada. If constructed, the repository would isolate nuclear waste in a stable geologic (rock) formation at least one thousand feet below ground. A combination of geologic feature and engineered components is expected to provide a series of barriers to prevent uncontrolled release of radionuclides into the environment. The barriers will include the chemical and physical form of the waste; the covering (cladding) on the fuel rods; the canister that will hold the waste; any packing material around the canister; and the natural characteristics of the rock formation itself.

The concept of geologic disposal of nuclear HLW and spent fuel has widespread international acceptance in much of the scientific community. Most of the studies to date suggest that, in a properly sited repository, the odds are very low that groundwater might leach radionuclides from the wastes and carry them to humans and the environment in health-threatening concentrations. 
Another subject of debate is how long nuclear HLW should be retrievable from a repository in case unexpected problems occur or in case future generations wish to recover the buried material. Current NRC regulations require that waste be retrievable for 50 years after a repository begins operation and that the retrieval be no more difficult than the initial excavation.

Some scientists cite the "Oklo" phenomena as convincing evidence in favor of disposing of nuclear HLW in stable geologic formations. Two billion years ago, natural events operating on a very rich uranium deposit in what is now Gabon, in Africa, led to nuclear fission reactions. This "natural" nuclear reactor produced the same types of wastes as today's reactors. Studies show that most of the fission products and virtually all of the TRU elements, including plutonium, have moved less than six feet from where they were formed 20 million centuries ago. 


\section{REFERENCES}

American Ceramic Society. (1991). Volume 23: Ceramic transactions: Nuclear waste management IV . Westerville, OH: Author

Bailey, R. (1993) . Eco-scam: The false prophets of ecological apocalypse . New York: St.Martin's Press.

Blake, E. M. (1993) Twenty nagging questions and not-necessarily-satisfying answers about LLW management in the United States . Nuclear news, $\underline{36}$, (15) 42-45 .

Brunner, C. E., (1993) . Hazardous waste incineration (2nd ed.) . New York: McGraw-Hill

Burleson, W. C., (1982) . The day the bomb fell on America . Englewood Cliffs, N.J.: Prentice-Hall

Cirrincione, D. A. \& Erdman, N. L., . (1992) Rocky Flats Plant site environment report for 1992 Golden, CO: EG\&G Rocky Flats, Inc.

Clinton climate plan sees nuclear power kept as it is. Nuclear news 36, (15) 22 .

Cohen, B. L. (1990). The nuclear energy option: An alternative for the 90s . New York: Plenum Press. 
Congress of the United States, Office of Technology Assessment. (1991) Long-lived legacy: Managing high-level and transuranic waste at the DOE nuclear weapons complex (OTA-BP-O-83) Washington, DC: U.S. Government Printing Office.

Coyle, D., Finaldi, L., Greenfield, E., Hamilton, M., Hedemann, E., McDonnel, W., Resnikoff, M., Scarlott, J., \& Tichenor, J. (1988) . Deadly defense: Military radioactive landfills . New York: Radioactive Waste Campaign.

Dolan, E. F., \& Scariano (1990) . Nuclear Waste: The 10,000-year challenge . New York: Franklin Watts.

Draper, E. L., (1993) A permanent ban on the dumping of radwaste at sea . Nuclear news, 36, (15) 17 .

Finland-to Russia fuel shipment draws protest . Nuclear news, $\underline{36}$, (15) 63 .

German tourist group warns against French trips . Nuclear news, $\underline{36}$, (15) 64 .

Gore, Senator A. (1992) . Earth in the balance: Ecology and the human spirit . Boston: Houghton Mifflin .

Lewis, H. W., (1990) . Technological Risk . New York: Norton

Miller, E. W., \& Miller, R. M. Environmental hazards: Radioactive materials and wastes Santa Barbara: Contemporary World Issues. 
Miller, G. T., Jr. (1992) Living in the environment: An introduction to environmental science (7th ed.) . Belmont, CA: Wadsworth

Nuclear Energy Policy Study Group. (1981). Nuclear power issues and choices (3rd ed.). Cambridge: Ballinger Publishing.

Nuclear Waste Technical Review Board . (1990). Second report to the U.S. Congress and the U.S. Secretary of Energy (Stock No: 061-000-00752-1). Washington DC: U.S. Government Publishing Office .

Nuclear Waste Technical Review Board . (1991). Third report to the U.S. Congress and the U.S. Secretary of Energy . Washington DC: U.S. Government Publishing Office .

NWTRB: Yucca Mountain project needs overall strategy . Nuclear news, $\underline{36}$, (15) 58.

Panel on Engineered Storage, Committee on Radioactive Waste Management, \& National Research Council . (1975) Interim storage of solidified high-level radioactive wastes . Washington, D.C.: National Academy of Sciences .

Radiation Effects: Low dose seen to help human cell repair system . Nuclear news, $\underline{36}$, (15) 71

Report tallies vessels, waste dumped in Arctic . Nuclear news, $\underline{36}$, (15) 62 .

Slovic, P., Flynn, H. F., \& Layman, M. (1991). Perceived risk, trust, and the politics of nuclear waste . Environment, $\underline{33}$ (N3) 6 . 
Tompkins, E. S., (1993) . Onsite dry spent-fuel storage: Becoming more of a reality .

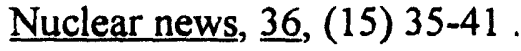

Wolfson, R., (1990). Nuclear choices: A citizen's guide to nuclear energy Cambridge: The MIT Press .

U.S. Department of Energy, Office of Civilian Radioactive Waste Management (1987) . Annual report to Congress . Oak Ridge, TN: Office of Scientific and Technical Information .

U.S. Department of Energy, Office of Civilian Radioactive Waste Management (1987) Monitored retrievable storage: Submission to Congress: Vol 1. The proposal. Springfield, VA: National Technical Information Service, U.S. Department of Commerce .

U.S. Department of Energy, Office of Civilian Radioactive Waste Management (1987) . Monitored retrievable storage: Submission to Congress: Vol 3, Monitored retrievable storage program plan Springfield, VA: National Technical Information Service, U.S. Department of Commerce .

U.S. Department of Energy, Office of Civilian Radioactive Waste Management (1987) . Additional information on: Monitored retrievable storage Springfield, VA: National Technical Information Service, U.S. Department of Commerce .

U.S. Department of Energy, Office of Civilian Radioactive Waste Management (1991) . Draft mission plan amendment . Oak Ridge, TN: Office of Scientific and Technical Information . 
Zacha, N. J., (1993) . Shooting fish in a barrel [editorial viewpoint] . Nuclear news $\underline{36},(15) 21$.

Zacha, N. J., Rippon, S., Blake, E. M., Taylor, G. M., Tompkins, E. S., \& FitzGerald, C. J. (Eds.) . (1993) . Waste management (Special issue) . Nuclear news, $\underline{36},(15) 17-57$

Zipko, S. J. (1990) Toxic Threat: How hazardous substances poison our lives . Englewood Cliffs, NJ: Julian Messner. 


\section{APPENDIX A -- COVER LETTER}

I am a student at Colorado Christian University. As a part of graduation, I have to complete a research project. You are asked to participate in the study. The current research involves nuclear waste storage.

All data gathered for the project is held in strict confidence. Your name and other identification are not requested. The results of this project will not be sold, formally published, or used for commercial profit. However, the completed project will be bound and placed in the university library. Other people will have access to it to read or use as reference text for other research.

If you would like a copy of the results of the study, please leave a self addressed envelope with the survey you return. Results will be mailed to you as soon as the project is completed. The anticipated completion date is September 12, 1994. 


\section{APPENDIX B -- QUESTIONNAIRE}

You are asked to participate in a study on the management of nuclear High-Level Waste (HLW) and Transuranic (TRU) waste storage. As you think of the nuclear HLW and TRU waste storage problem, please respond to the following statements as openly and honestly as possible by checking one, and only one, option per statement.

If you feel the statement is unclear or too technical, please check Unsure.

1. Circle your age group.

$16-21, \quad 22-30, \quad 31-40,41-50,50$ or older

2. Circle highest grade level obtained.

$8,9,10,11,12,13,14,15,16$ or higher

3. Do you have a technical background?

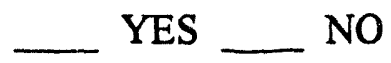

4. Check one.

MALE FEMALE

5. Nuclear waste storage technology is safe.

$-\quad$ Strongly Agree
$\square \quad$ Agree
$\square \quad$ Unsure
$\square \quad$ Disagree
$\square \quad$ Strongly Disagree

6. The solution to nuclear HLW and TRU waste disposal, is permanent storage in a geologic repository.

Strongly Agree

\begin{tabular}{ll}
$-\quad$ & Strongly Agree \\
$-\quad$ Agree \\
$\square \quad$ Unsure \\
$\square \quad$ Disagree \\
\hline$\quad$ Strongly Disagree
\end{tabular} 
7. I would oppose a permanent nuclear HLW and TRU waste repository in my state.

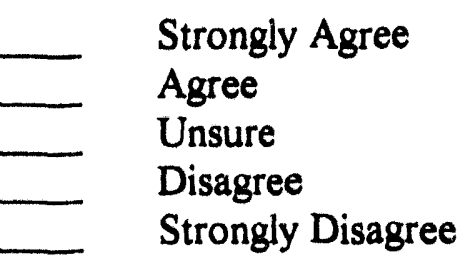

8. The safest way to handle nuclear HLW and TRU waste is through reprocessing. (reduces, but does not eliminate high-level waste)

\begin{tabular}{ll}
$-\quad$ Strongly Agree \\
\hline$\quad$ Agree \\
$-\quad$ Unsure \\
$\square \quad$ Disagree \\
\hline$\quad$ Strongly Disagree
\end{tabular}

9. It is safe to store nuclear HLW and TRU waste temporarily at present facilities until a permanent repository can be found.

\begin{tabular}{ll}
- & Strongly Agree \\
\hline & Agree \\
\hline & Unsure \\
$\square$ & Disagree \\
\hline & Strongly Disagree
\end{tabular}

10. While a decision is being debated on long term nuclear waste storage, nuclear HLW and TRU waste can be stored safely for an indefinite time frame.

\begin{tabular}{ll} 
__ & Strongly Agree \\
Agree \\
$\square \quad$ Unsure \\
$\square \quad$ Disagree \\
\hline$\quad$ Strongly Disagree
\end{tabular}

11. Nuclear HLW and TRU waste can be stored safely in an underground salt dome.

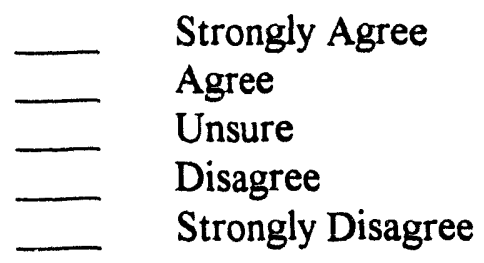


12. Vitrification is a viable process for long term storage of nuclear HLW and TRU waste.

\begin{tabular}{ll}
$-\quad$ Strongly Agree \\
$-\quad$ Agree \\
$-\quad$ Unsure \\
$-\quad$ Disagree \\
\hline & Strongly Disagree
\end{tabular}

13. Nuclear HLW and TRU waste can be safely dumped in the ocean.

Strongly Agree

$\begin{array}{ll}- & \text { Agree } \\ & \text { Unsure } \\ & \text { Disagree } \\ & \text { Strongly Disagree }\end{array}$

14. When nuclear HLW and TRU waste is buried according to the present plan, the estimated risk is ridiculously low.

$-\quad$ Strongly Agree
$-\quad$ Agree
$-\quad$ Unsure
$-\quad$ Disagree
$\square \quad$ Strongly Disagree

15. The public perception of nuclear HLW and TRU waste repositories is that they are not safe.

$\begin{array}{ll}- & \text { Strongly Agree } \\ & \text { Agree } \\ - & \text { Unsure } \\ -\quad \text { Disagree } \\ \square \quad \text { Strongly Disagree }\end{array}$

16. All nuclear HLW and TRU waste should be incinerated.

$\begin{array}{ll}- & \text { Strongly Agree } \\ - & \text { Agree } \\ - & \text { Unsure } \\ - & \text { Disagree } \\ & \text { Strongly Disagree }\end{array}$


17. A nuclear HLW and TRU waste repository and a nuclear power plant pose equal risk to the public, worker, and environment.

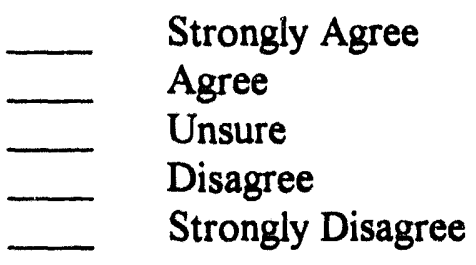

18. A nuclear HLW and TRU waste repository pose less risk than a nuclear weapons facility.

\begin{tabular}{ll}
- & Strongly Agree \\
$-\quad$ Agree \\
$\square \quad$ Unsure \\
$\square \quad$ Disagree \\
\hline & Strongly Disagree
\end{tabular}

19. A nuclear HLW and TRU waste repository pose less risk than a nuclear power plant.

$\begin{array}{ll}- & \text { Strongly Agree } \\ -\quad \text { Agree } \\ -\quad \text { Unsure } \\ -\quad \text { Disagree } \\ -\quad \text { Strongly Disagree }\end{array}$

20. It is safe to store nuclear HLW and TRU waste temporarily at Monitored Retrievable Storage (MRS) facilities until a permanent repository can be found.

\begin{tabular}{ll}
- & Strongly Agree \\
- & Agree \\
- & Unsure \\
- & Disagree \\
\hline & Strongly Disagree
\end{tabular}

21. The Office of Civilian Radioactive Waste Management has done a good job of educating the public about nuclear waste storage technology.

Strongly Agree

$\begin{array}{ll}\ldots & \text { Agree } \\ \ldots & \text { Unsure } \\ \ldots & \text { Disagree } \\ & \text { Strongly Disagree }\end{array}$ 
22. A nuclear HLW and TRU waste repository and a nuclear weapons facility pose equal risk to the worker, public, and environment.

$\begin{array}{ll} & \text { Strongly Agree } \\ - & \text { Agree } \\ \square & \text { Unsure } \\ -\quad \text { Disagree } \\ \square \quad \text { Strongly Disagree }\end{array}$

23. Nuclear HLW should be buried at the Yucca Mountain, Nevada if the site characterization study finds it is suitable.

- Strongly Agree

Agree

Unsure

Disagree

_ $\quad$ Strongly Disagree

24. Nuclear HLW and TRU waste should be rocketed into outer space.

\begin{tabular}{ll}
- & Strongly Agree \\
- & Agree \\
$-\quad$ Unsure \\
$-\quad$ Disagree \\
\hline$\quad$ Strongly Disagree
\end{tabular}

25. Nuclear waste should be permanently stored in a salt dome, at the Waste Isolation Pilot Plant (WIPP) in New Mexico.

Strongly Agree

$-\quad$ Strongly Agree
$-\quad$ Agree
$\square \quad$ Unsure
$-\quad$ Disagree
$\square \quad$ Strongly Disagree

\section{THANK YOU FOR TAKING THE TIME TO PARTICIPATE IN THIS SURVEY!}




\section{APPENDIX C - LEARNING OUTCOMES AT CCU}

\section{Concrete Experiences}

I learned that once the problem statement was more exactly defined, I had a clear direction in which to proceed. Clearly defining the problem statement in my case was only half the battle. I also discovered that the questionnaire is one of the most important tools available for the researcher to gather the needed data. Without the proper questions in the survey, the results of the project will be inconclusive. The data may provide enough information for the researcher to reach some generalizations, but the results will not be conclusive.

\section{Generalizations}

I felt overwhelmed at the beginning because some of my classmates had their problem statements clearly defined the first night of class. It took me several classes to decide on a problem statement and its sub-problems that I would feel comfortable working with for the rest of the school year.

\section{Skills Acquired}

My time management skills have improved during this school year. I had to learn to schedule my free hours to be able to handle the MHR core requirements, the research project, life-learning papers (LLP's), professional schools and training papers (PST's), and the week-end courses. I first developed labels on my monthly calendar for all my classes. I added any major papers due and prioritized my daily task list. This was a tremendous help in that it kept me focused and allowed me to meet all my class requirements on 
schedule. Before starting this class, I always kept a "To Do List," but I had to make it more long-range and commit to following it religiously. It was a pleasure and feeling of accomplishment marking off each milestone as it was completed.

I also enhanced my reading skills. The inspectional reading technique was a big help, because I had so much material available, I had to be able to skim the material quickly, and then make a decision on where to concentrate my efforts.

My critical thinking skills also improved. I have opened my mind to the possibility that there may be alternative methods to the nuclear HLW disposal issue. From my research during this project, I have come to discover that Monitored Retrievable Storage (MRS) has a lot of merit and that maybe we should allow ourselves adequate time to properly investigate more of these alternate methods.

I have discovered that the respondents to the survey seem to generalize and do not appear to understand the factual basis of the nuclear HLW and TRU waste disposal issue. I must admit that I had made similar generalizations, until I got the opportunity to research the information available thoroughly. I also have a better appreciation for how many different viewpoints on this subject are in print. When reading a book presented by an environmentalist, it is all doom and gloom, while some of the more technical books think we should be operating repositories today.

\section{Personal Reflections}

I appreciated the opportunity to research and improve my understanding of the nuclear HLW and TRU waste issues. I have been working in the nuclear field since 1980 and have generally felt comfortable with everything the industry was doing, except for the 
waste problem. Now that I have had the chance to thoroughly research the issues, I feel even more comfortable with the accomplishments and progress of the technical and scientific community. They do not have all the answers at this time, but due to the high visibility, I feel they will make the right political and moral decisions.

The only negative feeling I experienced during the research project was at the very beginning, when I walked into class the first night and had absolutely no idea what was expected of me. I would like to recommend that during orientation the students be briefed on the research project and how to go about deciding a subject. Make them aware that they need to start thinking of possible project problems.

I entered this program because it offered me the quickest opportunity to obtain a Bachelor of Science degree that would allow me to start the master's program at the University of Denver sooner. I have been pleasantly surprised by what I have learned over the school year. I believe I have become a better and more understanding person. I feel my writing skills have improved and that I can communicate verbally and non-verbally at a higher level than when I came to Colorado Christian University.

I feel more comfortable in group situations. I still do not like to give presentations or speeches, but through the MHR program I have gained the courage to try and improve in that area. When I start at the University of Denver I will be working on a dual master's program in "Environmental Policy and Management" and "Applied Communication." I would like to thank my professors at Colorado Christian University for helping me to improve as a person. 

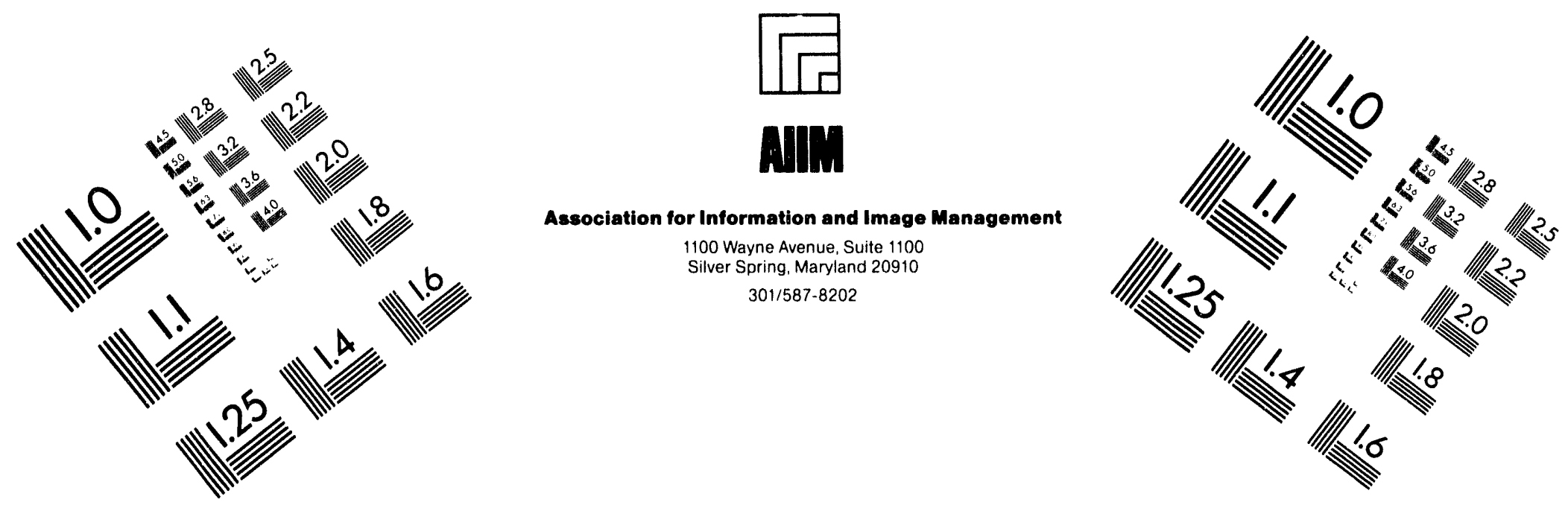

\section{Centimeter}

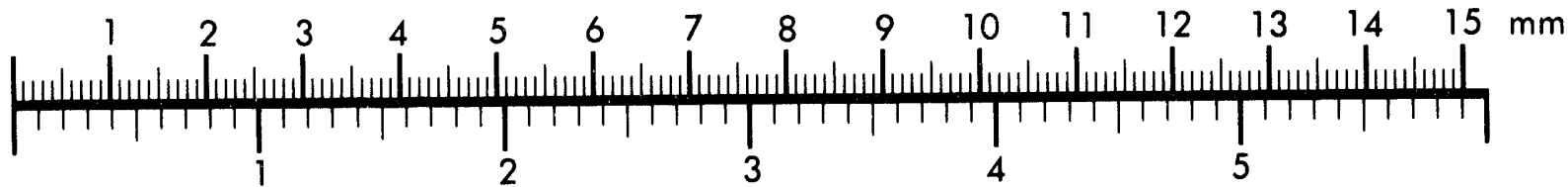
Inches
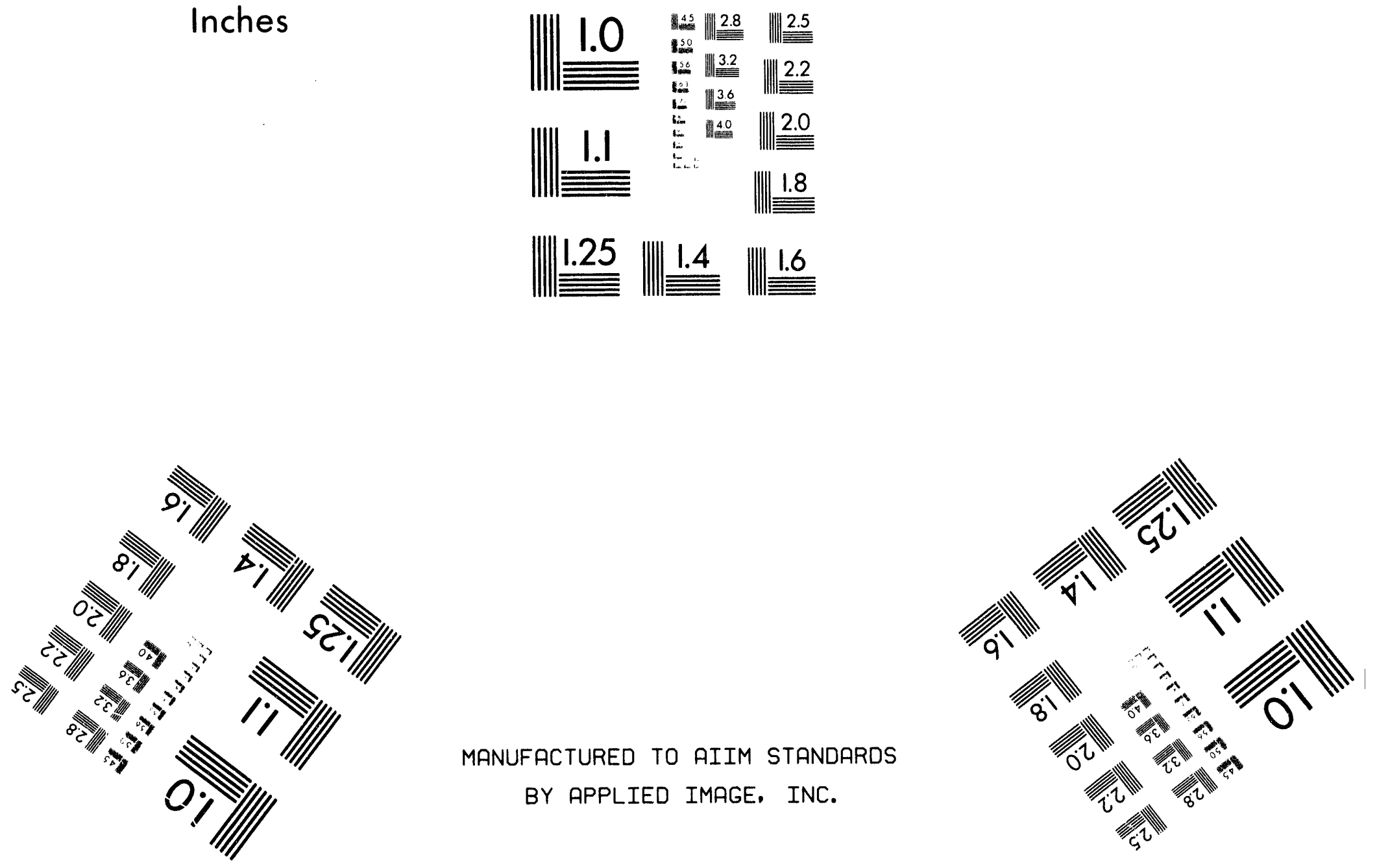


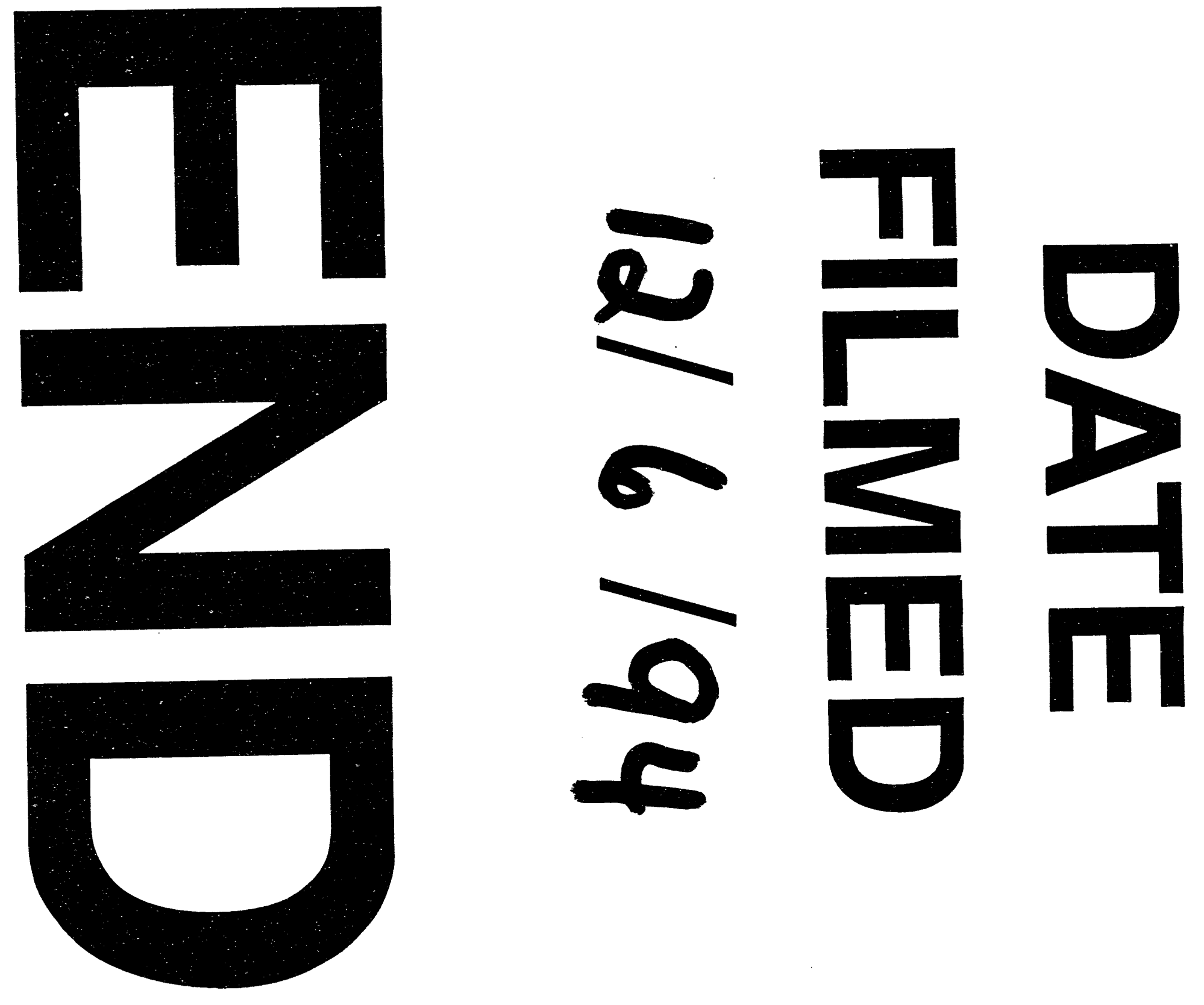